\title{
What Drives the Persistent Competitiveness of Small Banks?
}

\author{
Bill Bassett and Tom Brady
}

$5 / 24 / 02$

\begin{abstract}
Several trends in the financial industry could have weakened the competitiveness of small banks in recent years including consolidation and improved financial strength of large banks, competition from nonbank financial firms, and a decline in the real value of deposit insurance. Despite those challenges, small banks have grown more rapidly than larger banks over the period from 1985 to 2001, and their profitability has been sustained at high levels. However, small banks have needed to increase the interest rates offered on deposit accounts in order to attract progressively more deposit funding. In this paper, we provide empirical evidence that this increased interest cost primarily reflects the higher rate of return that small banks were able to earn on their assets. Moreover, we show with an arbitrage model that the decline in the real value of deposit insurance has only a small effect on deposit rates as long as bank failure rates are in the low range of recent years.
\end{abstract}

The view in this paper are those of the authors and do not represent the views of the Federal Reserve System, the Board of Governors, or its staff. This paper has benefited from very useful comments from Rafael Bostic, Bill English, Ed Ettin, Diana Hancock, Myron Kwast, Athanasios Orphanides, Brian Sack, and Egon Zakrajsek. The authors thank Jimmy Cypert and Mark Gibson for excellent research assistance. 
The Federal Deposit Insurance Corporation's (FDIC) proposal for the modernization of deposit insurance has recently been the focus of considerable attention (FDIC 2000). As part of its proposal, the FDIC would raise the current $\$ 100,000$ ceiling on coverage in order to account for the erosion of its real value by inflation since it was set in 1980 (Chart 1). ${ }^{\square}$ The decline in the real value of deposit insurance would tend to raise the cost of funding assets with deposits, and thus could adversely affect banks that tend to rely heavily on deposits. Large banks, which fund themselves relatively more in the uninsured wholesale markets, could be less affected than small banks.

The decline in the real value of deposit insurance, however, is only one of several trends in the financial industry that could have weakened the competitiveness of small banks in recent years. Among these other developments have been the return to health of large banks, numerous mergers that have increased the size and scope of large banks, and the continued increase in competition from mutual funds and other nonbank financial companies.

Mergers and acquisitions have reduced the number of banks in the United States from more than 14,000 in 1985 to about 8,300 at the end of 2000 , and during this time the share of domestic banking assets held by the largest 100 banks rose from about half to almost three-fourths (Chart

\footnotetext{
${ }^{1}$ Depending on the price index used, the real value of deposit insurance, expressed in 1980 dollars, has fallen to between $\$ 45,000$ and $\$ 55,000$ by the end of 2000 . Thus, by many measures the real value of deposit insurance is still slightly higher than it was prior to the substantial increase from $\$ 40,000$ to $\$ 100,000$ in 1980.

2 Thompson [2001] provides an excellent overview of the implications of increasing the deposit insurance limit for various groups of individuals, non-financial firms, and the banking industry.
} 


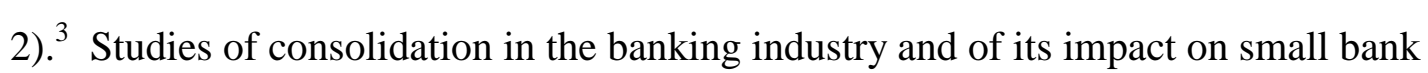

competitiveness have reached differing conclusions. ${ }^{\square}$ However, consolidation interacts with the decline in the real value of deposit insurance to create another potentially adverse impact on the competitiveness of small banks. The creation of "mega-banks" increases the possibility that depositors would consider these larger banks to be "too big to fail" (TBTF), which would implicitly confer a greater level of deposit insurance upon large bank customers than those of small banks. ${ }^{\text {G }}$ Smaller banks contend that an increase in the nominal value of deposit insurance is needed to help offset this perception of a TBTF policy (Independent Community Bankers Association [2000]).

The evolution of large, complex banking organizations has led federal bank regulators to warn that these institutions create the potential for unusually large systemic risks to the national and international economies should they fail (Greenspan [1999]). However, the Federal Deposit Insurance Corporation Improvement Act of 1991 (FDICIA) circumscribed regulators' ability to invoke TBTF. It required that the FDIC pursue the resolution method that poses the least cost to its insurance fund when dealing with a failed bank, and stipulated that exceptions to the "least

\footnotetext{
${ }^{3}$ Berger, et. al. [1995] provide an excellent overview of banking consolidation through the mid-1990s.

${ }^{4}$ Some authors have found that large acquiring banks often lose a significant share of pre-merger customers to locally headquartered small banks (Nakamura [1994], Pilhoff and Rhoades [2000]). However, researchers have found that mergers improve large banks' profit performance by allowing them to move out along the risk vs. expected return spectrum while relying on the added diversification to mitigate risk and capital charges (Akhavein, Berger, and Humphrey [1998]; Demsetz and Strahan [1998]). The evidence as to whether mergers help large banks become more cost efficient is also mixed (Rhoades [1994] and Peristiani [1997]).

5 The perception of a TBTF policy stems from the Congressional testimony of the Comptroller of the Currency in September 1984, in which he strongly implied that the deposits of the eleven largest banks would be fully insured in the event of failure. O'Hara and Shaw [1990] found that the Wall Street Journal's interpretation of the announced TBTF policy had a positive effect on the stock prices of the eleven banks mentioned, and that the effect varied according to bank solvency. Black et. al. [1997] found that the market's perception of the riskiness of other large banks also declined after the testimony.
} 
cost" method must garner the approval of super majorities of both the Federal Reserve and FDIC boards plus that of the Secretary of the Treasury in consultation with the President of the United States. Angbazo and Saunders [1997] found the cost of funds to large banks increased after FDICIA was implemented, suggesting that bank creditors believed that FDICIA reduced the likelihood of a large bank benefiting from a TBTF policy. Moreover, bank regulatory agencies maintain that no bank is too large for shareholders and nondeposit liability holders to face complete loss, and for uninsured depositors to be subject to less than 100 percent reimbursement, should the decline in bank asset values be large enough (Greenspan [2001]).

In addition to the consolidation of the banking system, the continued growth of nonbank financial institutions may have weakened the competitive situation of small relative to large banks in recent years (D'Arista and Schlesinger [1993]). Although savings and loan associations, credit unions, mutual funds and finance companies compete with banks of all sizes, they likely pose a greater competitive challenge to smaller banks. In addition to being more dependent on deposit funding than the larger banks, small banks also tend to be more concentrated than large banks in the types of loans extended by finance companies (Dynan, Johnson, and Slowinski [2002]). Over the period studied, however, an outright decline in thrift industry assets offset the added competition from other types of nonbank financial companies, particularly money market mutual funds.

In the late 1980s and early 1990s, the competitive position of small banks likely was boosted as a result of the more severe deterioration in asset quality at large banks, and the wider gap at large banks between actual capital levels and those being demanded by markets and the new Basle 
accord (Chart 3). However, the subsequent economic recovery and brisk expansion of the second half of the 1990s caused delinquency rates to drop dramatically, particularly at large banks. At the same time, the gap between the leverage ratios small banks and large banks also narrowed noticeably, as large banks boosted their capital following the implementation of the Basle Accords in 1991.

Despite the aforementioned headwinds affecting small banks' competitiveness, Bassett and Brady [2001] found that small banks have grown more rapidly than larger banks over the period from 1985 to 2000 . Moreover, they showed that small banks have largely maintained or even increased their levels of profitability throughout much of the period studied, despite paying increasingly large premiums on their deposits relative to large banks in order to fund their more rapid asset expansion. The purpose of this study is to extend this research by more formally examining the differential impact of the influences mentioned above on the competitive performance of small banks over the period from the mid-1980s to 2001.

First, we employ an arbitrage model to examine the relationship between relative average interest rates on deposits at small and large banks, the level of deposit insurance, bank failure rates, and perceptions about TBTF. The model demonstrates that the sensitivity of relative deposit rates to the level of deposit insurance or views about the importance of TBTF is quite low when bank failure rates are low, as they have been in recent years. We then present econometric evidence

\footnotetext{
6 The equity to assets ratio is shown here because it can be computed before the implementation of the Basle Accord in 1991. Over the past decade, small banks also have had significantly greater capital ratios than large banks when measured by risk-weighted assets. Compared with conditions at larger banks, the higher capital ratios at small banks may reflect, in part, the higher risk inherent in their relatively less diversified loan portfolios and their more limited access to markets for managed liabilities.
} 
suggesting that the rising relative cost of deposits at small banks vis-à-vis large banks over the past decade largely reflects small banks' need to attract funding to sustain their aggressive and profitable asset expansion. The share of uninsured deposits, which has risen as the real value of deposit insurance has declined, and a marked improvement in the balance sheet health of large banks during the 1990s played somewhat smaller roles in boosting deposit rates at small banks.

The next section describes the data used in the article and identifies some key balance sheet differences between large and small banks. Section III illustrates that small banks have been able to grow faster than large banks by offering better deposit rates and that the premium they pay has been rising over time. Section IV presents an arbitrage model of deposit pricing at large and small banks that incorporates deposit insurance and "Too Big To Fail” effects. Section V presents regression estimates from a reduced form model of deposit rate determination at large and small banks. Conclusions are presented in section VI.

\section{Data and Summary Statistics}

Except where otherwise indicated, data in this paper are from the quarterly Reports of Condition and Income (Call Reports) for the domestic offices of insured domestically chartered commercial banks and nondeposit trust companies (hereafter, banks). In this article, large banks are those ranked 1 through 100 based on assets at the start of each quarter. Small banks are those ranked outside of the largest $1,000 .^{\square}$ At the start of the fourth quarter of 2000 , large banks had assets of at least $\$ 6.94$ billion, while all small banks had assets of less than $\$ 331$ million.

\footnotetext{
${ }^{7}$ Banks are assigned to large and small categories based on their relative ranking rather than an absolute dollar amount of assets to avoid "drift" caused by inflationary increases in banks assets over the time period studied. It is important to note also that the unit of observation is commercial banks rather than independent banking
} 
A. Key balance sheet differences between small and large banks.

Small banks rely considerably more on deposits than do large banks. In particular, small time deposits (those issued in amounts of less than $\$ 100,000$ ) funded almost 30 percent of loans and other assets at small banks in 2000, while at large banks the share was 10 percent (Table 1). The share of small banks' assets funded with large time deposits, 13 percent, also exceeds that at large banks, 8 percent. ${ }^{\square}$ Other interest-bearing deposits, which consist of savings and transactions accounts, also were somewhat more important funding vehicles at small banks, while noninterest-bearing deposits funded comparable shares of small and large banks' assets in 2000.

Large banks funded about one-third of their assets with "other" nondeposit liabilities in 2000, whereas at small banks the share was just 3 percent. ${ }^{-1}$ Small banks availed themselves somewhat more of FHLB advances, although these represent a fairly small share of liabilities at both groups of banks. Equity also funded a larger share of assets at small than at large banks, 10.3 percent and 8 percent respectively.

Reliance on deposits changed little between 1987 and 1992, but both bank groups shifted toward

organizations (including independent banks and bank holding companies). Currently, the 100 largest banks roughly represent the top 70 bank holding companies.

${ }^{8}$ For more on the economic performance of banks over the 1985-2000 period, see, for 2000, Bassett and Zakrajsek [2001], and the corresponding article in one of the June-September issues of the Federal Reserve Bulletin in each of the earlier years.

${ }^{9}$ Large time deposits are those of at least $\$ 100,000$. Deposits of exactly $\$ 100,000$ would be fully insured as to principal.

${ }^{10}$ Other liabilities consist of demand notes issued to the U.S. Treasury, federal funds purchased and securities sold under repurchase agreements, trading liabilities, net due to related institutions abroad, subordinated debt or debentures, and bankers acceptances. 
nondeposit liabilities and capital as sources of funding during the 1990s. Between 1992 and 2000, deposits as a share of assets fell about 4 percentage points at small banks and 10 percentage points at large banks. For both bank groups, "other interest-bearing deposits" was the deposit category that fell most in the 1990s, although at large banks "non-interest-bearing deposits" declined almost as much. Small time deposits (which are fully insured) declined by similar amounts at both bank groups, a drop probably reflecting the increased popularity of alternative household investment vehicles such as mutual funds. However, the share of assets funded by large time deposits actually increased at both bank groups, with a larger increase posted at small banks.

At small banks, the type and average size of large deposit accounts (all those of at least $\$ 100,000)$ are notably different from those at large banks (table 1, memo). At large banks, only about 30 percent of such balances were held as large time deposits in 2000; the remaining 70 percent were in transaction and savings accounts. At small banks, large balances are split about evenly between large time and other deposits. The average size of large deposits at large banks in 2000 was $\$ 425,000$, and at small banks it was $\$ 229,000$; however, over the 1990 s the average size declined at large banks and rose at about the rate of inflation at small banks.

\section{B. Growth patterns for large and small banks.}

As noted, the mergers that have been the vehicle of consolidation typically have involved the acquisition of smaller banks by much larger banks. This, of course, boosts measured growth of large banks and diminishes that of small banks. To account for this in examining the balance 
sheet growth and profitability of small vis-à-vis large banks, we merger-adjust data from the quarterly Reports of Condition and Income, filed by all federally insured commercial banks. 11

Balance sheet data adjusted for mergers show that small banks generally have grown faster than either medium-sized or large banks over the past fifteen years (chart 4, top panel). Indeed, in every year, the growth of assets has been significantly faster at small banks than at large banks. $\frac{12}{\square}$ Of course, banks securitize and sell a significant portion of the consumer and real estate loans that they originate and thereby move them off their balance sheets. But data available since 1997 indicate that restoring securitized credit card loans to large banks' balance sheets would not narrow the difference in growth rates significantly. ${ }^{13}$ Of course, adding securitized assets to the balance sheet for purposes of comparison presumes that the securitizing bank still would have chosen to originate the loans even if the opportunity to securitize was not available.

In addition, an average of about 350 new, or "de novo," banks were formed each year during the 1997-2000 period, compared with about 150 per year during the preceding four years. Although de novo banks tend to grow rapidly, the growth rate of all small banks is not significantly

\footnotetext{
${ }^{11}$ For each bank size group, merger-adjusted growth for any balance sheet item during a quarter is calculated using reported values at the end of the quarter and values at the beginning of the quarter constructed to take into account mergers during the quarter and income statement items are adjusted based on the accounting method (purchase or pooling) used in the merger. For a description of the merger adjustment process for income see, English and Nelson [1997].

${ }^{12}$ Calculated without adjusting for mergers, the average annual growth rate of assets between 1985:Q4 and 2000:Q4 was 0.2 percent for small banks and 8.2 percent for large banks. The growth rates of assets at independent small banks, while somewhat lower than those of small banks affiliated with larger bank holding companies, also exceed those of the largest 100 banks.

${ }^{13}$ Residential real estate loans are also commonly securitized, but data was not available prior to 2001. Moreover, the government-sponsored entities that purchase home mortgages buy from both large and small banks, whereas securitizations of credit card portfolios are undertaken by individual banks, and thus require a certain scale of operations in order to be feasible.
} 
affected if de novo banks are excluded from the calculation. Moreover, the accelerated pace of entry into a fast growing sector provides substantial evidence of the attractiveness of small banks to investors.

As suggested by the relative rates of merger-adjusted asset growth, the expansion of total deposits at small banks has also exceeded the growth rate at large banks in every year since 1985, after adjusting for mergers (chart 4, middle panel). Uninsured deposits also grew significantly faster at small banks than at large banks (chart 4, bottom panel). Furthermore, the growth rate of uninsured deposits at small banks has been high and steadily increasing during the second half of the past decade, whereas at larger banks the growth of these liabilities shows no trend. However, the growth of assets tended to exceed that of deposits, as the use of nondeposit liabilities grew for all bank size groups.

\section{How Have Small Banks Expanded Deposits Faster Than Large Banks?}

Chart 5 examines the connection between relative rates paid on deposits at small and large banks and relative deposit growth rates, for various definitions of deposits. ${ }^{14}$ The solid line in all four panels is the difference, expressed in basis points, between the average interest rates paid for deposits by small and large banks. Similarly, the dotted line depicts the growth rate of deposits at small banks less the growth rate at large banks, expressed in percentage points.

14 Average deposit rates are computed as quarterly interest expenses, annualized, as a percent of average deposits held over the quarter. Annual rates are averages of quarterly rates. Both average deposit levels and deposit expenses are calculated on a merger-adjusted basis. 
Growth of total interest-bearing deposits at small banks consistently exceeded that at large banks between 1985 and 2000 by amounts that tended to reflect movements in the spread between deposit rates paid at small relative to large banks (Chart 5, upper left). ${ }^{15}$ As the period began, small banks were outbidding large banks for deposits, but this relationship reversed in the late 1980s and into 1990, a shift that seemed to prompt a relative acceleration of growth of deposits at large banks. During the 1991-93 period, small banks raised their average rate paid on interestbearing deposits by about a full percentage point relative to rates at large banks, restoring the premium paid by them in the mid-1980s. Evidently as a result, the growth rate of deposits at small banks rose substantially compared with that at large banks during these years. However, even though the deposit rate spread favoring small banks remained elevated and, on balance, rose somewhat over the course of the 1990s, the amount by which deposit growth at small banks exceeded that at large banks trended down over most of the decade.

The remaining panels present the same relationship between relative deposit offering rates and relative deposit growth rates for deposits disaggregated into small time, large time, and other interest-bearing deposits. This greater detail reveals that the positive correlation between relative offering rates and relative deposit growth rates at small banks generally held up for small time deposits over the entire period examined, but tended to diminish during the latter 1990s in the large time and "other" deposit components. The difference between the behavior of small time

\footnotetext{
${ }^{15}$ The average interest rate paid on deposits is obviously affected by the maturity distribution of those deposits. For instance, since 1997 the average maturity of large time deposits at small banks apparently has been increasing, while no clear trend has emerged at large banks, which would account for some of the spread widening, given a generally upward sloping yield curve. Unfortunately, the maturity distribution for large and small time deposits is reported only in three or four rather crude categories and neither the number of categories nor the maturity ranges are consistent over the whole period studied.
} 
and the remaining categories of interest-bearing deposits may reflect the fact that small time deposits are (by definition) fully insured while the other categories have large uninsured components.

The relative rise in deposit interest rates, however, did not significantly affect small banks' profitability, as the rise was apparently offset by higher rates earned on assets at small banks. Net interest margins (NIM) at small banks have traditionally been substantially greater than at the largest 100 banks, and during most of the second part of the 1990s, the NIM at small banks held steady, while it edged down at large banks (Chart 6). In part, small banks maintained their NIM by increasing the share of their portfolios held as loans- - which, on average, earn higher yields than securities - throughout the 1990s. Although the NIM at small banks began to narrow somewhat more over the past three years and fell below its late 1980s level, that decline has been matched by a similar fall off at large banks.

Turning to broader measures of profitability, return on equity (ROE) at large banks has stabilized around an average of about 15 percent throughout the mid- to late-1990s. Small banks ROE has also been fairly stable during the 1990s, and is uniformly above the returns earned during the late-1980s. While ROE at large banks has been significantly greater than ROE at small banks since 1992, this is in large part due to the much greater levels of capital relative to assets held by small banks.

\footnotetext{
16 As can be shown from the data in table 1, insured deposits outside of small time deposits were 25.8 percent of total assets at large banks in 2000 while total deposits outside of small time amounted to 46.3 percent of total assets. Thus, 25.8/46.3 or 55.7 percent of deposits outside of small time were insured and 44.3 percent uninsured. At small banks, the uninsured share in 2000 was smaller, 27 percent.
} 
In terms of the return on assets (ROA), small banks have generally been more profitable than large banks (Chart 6, bottom right panel), an achievement that is especially impressive given the greater (and growing) earnings on off-balance-sheet activities at large banks. Indeed, the jump of large banks' ROA over that of small banks in 1999 is attributable to large gains in revenue from capital markets business and trading operations; such revenue is not a significant portion of income at small banks.

\section{Modeling the Supply and Demand for Deposits at Small and Large Banks}

As shown above, deposit inflows at small banks have demonstrated a progressively smaller response to relatively higher deposit offering rates over the 1990s. Among the potential explanations is the declining real value of deposit insurance. The next section presents an arbitrage model that allows us to calculate the impact of deposit insurance coverage on uninsured deposit rates at small banks relative to large banks for different deposit sizes and for different assumptions about perceived probabilities of failure and of government bailouts of depositors at large banks. Following that, we develop a regression model to test the influence on relative deposit rates of the real value of deposit insurance and other factors, including balance sheet health and the extent of nonbank competition for deposits.

A. An Arbitrage Model of Deposit Rate Premiums with Deposit Insurance and Too Big To Fail

The expected return on a large time deposit held at an individual bank can be written as:

$$
\left(1-p_{i}\right)\left(1+r_{i}\right)(y+x)+p_{i}\left(y+b_{i} x\right)
$$


where, $\mathrm{i}=\mathrm{L}, \mathrm{S}$ for Large Banks and Small Banks, respectively

$\mathrm{p}_{\mathrm{i}}=$ expected probability of a failure of bank type $i$ while the investor is exposed

$\mathrm{r}_{\mathrm{i}}=$ interest rate paid on large time deposits at bank type $i$

$\mathrm{x}=$ size of the uninsured portion of the large time deposit

$\mathrm{b}_{\mathrm{i}}=$ fraction of the uninsured deposit expected to be recovered if bank type $i$ fails or is taken over by the FDIC

$\mathrm{y}=$ statutory insured deposit amount

If investors in bank deposits believe that there is a TBTF policy then-other things equal- $b_{L}$

would be larger than $b_{\mathrm{S}}$. ${ }^{\square}$ It is important to note that, in the event of an FDIC payout, only the principal amount is protected (in part or in whole) and not the accrued, but unpaid, interest.

Consistent with historical experience, we assume that the probability of failure of a large bank is

a fraction of the probability of failure of a small bank, so that:

$$
\mathrm{p}_{\mathrm{L}}=a \mathrm{p}_{\mathrm{S}} ; \quad 0<a<1
$$

where $a$ denotes the fraction. Small banks compete by posting deposit rates that equate investors' expected utility from deposits at their bank with that on deposits at large banks.

Depositors are assumed to be risk averse with logarithmic utility functions over expected returns.

The above assumptions imply that $r_{S}$ must satisfy the following equation:

17 "TBTF" here refers to a belief by depositors that uninsured deposits at some very large failed banks will be better protected than at other banks (given the share of a bank's liabilities that are uninsured and the bank's capitalization), presumably on the rationale that such a policy would help prevent other bank failures by limiting contagion effects.

${ }^{18}$ Implicitly we are also assuming that individuals hold the entire deposit in one account at one bank. The depositor could increase the fraction of the deposit that is insured by opening multiple accounts under different ownership interests at the same bank or by holding deposits at more than one bank. However, the transaction costs associated with doing so appear to be large enough to push the average large time deposit above $\$ 200,000$ at small banks. 


$$
\left(1-a p_{S}\right) \ln \left[\left(1+r_{L}\right)(y+x)\right]+a p_{S} \ln \left[y+b_{L} x\right]=\left(1-p_{S}\right) \ln \left[\left(1+r_{S}\right)(y+x)\right]+p_{S} \ln \left[y+b_{S} x\right]
$$

Further, assume that the average large time deposit rate at large banks is 5.50, which is representative of the average rate on such deposits at large banks over the past several years. For purposes of assigning deposit insurance premiums, historical FDIC reserving behavior suggests that, on average, the smallest banks are four times more likely to fail than large banks, thus $\mathrm{a}=1 / 4$. In Table 2 , we consider the spread that a small bank would have to pay on a $\$ 250,000$ large time deposit, which is representative of an average-sized, large time deposit at small banks over the past several years.

When the probability of a small bank failure is set at the approximate rate of failure observed from 1998-2001 for all banks (that is 0.025 percent per quarter) and deposit insurance is set at $\$ 100,000$, the deposit rates paid by small banks are predicted to be only marginally higher than at large banks (column 4). Doubling the amount of deposit insurance reduces the spread paid by small banks by only 2 to 4 basis points under reasonable assumptions about the fraction of uninsured deposits that will be returned to investors in the event of a bank failure (column 5). Even when the fraction of uninsured deposits that are recovered is assumed to be highly unfavorable to small banks, that is, depositors of a failed large bank recover 100 percent of their uninsured accounts while a small bank depositor receives nothing, the spread only widens to 7 basis points.

It is only when annual rates of small bank failure begin to approach the levels seen in the early 1990s (more than 1 in 100 annually, 0.25 percent per quarter) that spreads widen noticeably for small banks. With the current level of deposit insurance and a 0.25 percent probability of failure 
in a given three-month interval, the spread between interest rates at large and small banks widens to more than 25 basis points (rows $5-8$ ). When the expected loss to uninsured depositors at small banks is significantly larger than it is at large banks (such as may be the perception under TBTF), the premiums paid by small banks increase to more than 50 basis points (rows $7-8$ ).

Doubling the amount of deposit insurance to $\$ 200,000$ under these assumptions results in a noticeable decline in the spreads that small banks pay for uninsured deposits (column 6, rows 5-8). The spread paid by small banks would be about 40 basis points lower than it would be with the current $\$ 100,000$ coverage amount when the expected payment to uninsured depositors is 50 percentage points greater at large banks (row 7). However, the premiums and the benefit of additional insurance in this instance may be overstated by the use of historical rates of default as benchmarks, because doing so assumes all failures occur too suddenly for uninsured deposits to be withdrawn before the bank is taken over by regulators.

\section{B. A Regression Model of Deposit Pricing}

\section{The Model}

Banks are assumed to set their deposit offering rates based on the return they can earn on the deposit funds attracted, their capacity to lend as determined by required and desired capital ratios, and on the demand for their deposit products, an important factor in determining intermediation spreads. These can be captured in a model of demand for and supply of deposit funding for each bank group.

$$
\mathrm{Q}_{\mathrm{d}}=\mathrm{D}\left(\mathrm{RD}, \mathrm{R}^{\mathrm{a}}, \mathrm{DI}, \mathrm{K}, \mathrm{Y}\right)
$$


Where:

$$
\begin{aligned}
& \mathrm{Q}_{\mathrm{s}}=\mathrm{S}(\mathrm{RD}, \mathrm{ROL}, \mathrm{K}) \\
& \mathrm{RD}=\mathrm{RD} * \mid \mathrm{Q}_{\mathrm{d}}=\mathrm{Q}_{\mathrm{s}} .
\end{aligned}
$$

$\mathrm{Q}_{\mathrm{d}}, \mathrm{Q}_{\mathrm{s}}=$ quantity of deposits demanded and supplied, respectively

$\mathrm{RD} \quad=$ real interest rate on deposits

$\mathrm{R}^{\mathrm{a}} \quad=$ vector of real interest rates on similar products, including deposits at competing banks

$\mathrm{K} \quad=$ measure(s) of capital adequacy

DI $=$ real value of deposit insurance

$\mathrm{Y}=$ real gross domestic product

$\mathrm{ROL}=$ total return on loans net of loan loss provisioning

If we assume the equations are linear, then we can solve for the equilibrium interest rate on deposits for each bank size group $i$, with reduced form coefficients:

$$
\mathrm{RD}_{\mathrm{i}}=\mathrm{a}_{0}+\mathrm{a}_{1} \mathrm{ROL}_{\mathrm{i}}+\mathrm{a}_{2} \mathrm{R}^{\mathrm{a}}+\mathrm{a}_{3} \mathrm{Y}+\mathrm{a}_{4} \mathrm{~K}_{\mathrm{i}}+\mathrm{a}_{5} \mathrm{DI}+\mathrm{u}_{\mathrm{i}}
$$

Because banks profit by raising deposit rates to attract more loanable funds when the return on loans is high, the expected sign on $a_{l}$ is positive. Higher alternative rates, such as the T-bill rate and the interest rate offered by the competing bank size group, should require banks to raise deposit rates for competitive reasons, thus the expected signs on the vector of coefficients $a_{2}$ are also positive. Higher incomes should strengthen demand for a bank's deposits and put downward pressure on offering rates, thus $a_{3}$ should be negative, everything else equal.

The impact of measures of balance sheet health on deposit rates is indeterminate, since they affect both the supply and demand for deposits. Higher capital ratios would add to a bank's ability to lend and so would be expected to lead to an increase in its deposit offering rates. However, rising capital ratios should also boost the demand for its liabilities, particularly uninsured liabilities, which would tend to reduce offering rates on deposits. Thus, $a_{4}$ does not 
have an expected sign.

The nominal value of deposit insurance was unchanged at $\$ 100,000$ over the entire estimation period. The real value of deposit insurance declined, however, which would tend to raise the average deposit rate necessary to attract a given quantity of deposits. This effect would be greater for small banks to the extent that depositors give credence to TBTF or perceive small banks to be riskier than large banks. Therefore, we expect $a_{5}$ to be positive and, to the extent that either of the above assertions about depositors is accurate, to be larger for small banks than for large banks.

Specifying an empirical measure of the real value of deposit insurance in the regression model is not straightforward, however. Because the real value of deposit insurance changed only as a result of inflation over the time period studied, and the price level acts as though it were a unit root process, the real value of deposit insurance over this time will also be a unit root process. Thus, the results of a regression that includes the real value of deposit insurance would be spurious (Greene 1993). Instead, we use the uninsured share of total deposits. Although the share of deposits that is uninsured could change for several reasons - a change in the balance sheet health of a bank or depositor risk preferences, for example-over time, it should rise as the real value of deposit insurance falls.

\section{Estimates for Rates on All Deposits}

We present the results from several specifications based on the above regression model in Table

3. In order to account for persistence in deposit rates, and some characteristics of deposits for 
which we cannot include a more appropriate variable, we include a lagged dependent variable in each regression. The two equations, one for each bank group, are estimated jointly using the method of Seemingly Unrelated Regression with instrumental variables. Each bank-size-groupspecific variable is treated as endogenous and instrumented with its lagged value from two quarters earlier, and the lagged dependent variable is instrumented with its value three quarters earlier. ${ }^{19}$ The share of total deposit liabilities held by money market mutual funds and thrifts is used as a proxy variable for the amount of competition banks are getting from nonbank financial firms, and it is also treated as endogenous. Other macroeconomic variables, detailed below as appropriate, were added to some of the specifications in order to test the robustness of the estimated coefficients on the main variables of interest.

The coefficients on the equity to assets ratios in these equations are negative and generally significant, especially for large banks, suggesting that the effect of a bank's capitalization on demand for its deposits outweighs its supply effects. Thus, the rapid increase in capital ratios at large banks after the early 1990s probably significantly raised their competitiveness vis-à-vis small banks. However, in two of the specifications, the coefficient on this variable is insignificant for small banks, suggesting that capital as a supply factor may play a larger role in that sector, with well capitalized small banks aggressively pricing deposits to fund expansion. Alternatively, variation in the capital ratios maintained by small banks over the time period may not have noticeably affected small bank deposit rates because their generally high levels are

\footnotetext{
19 The second lag needs to be used as an instrument because of the presence of a lagged dependent variable on the right hand side of each equation. The presence of the interest rate at the competing bank size group is what makes it necessary to have an instrument for the lagged dependent variable, and the third lag of the dependent variable is used because the second lag is already being used as an instrument for deposit rates at the competing bank size group.
} 
sufficient to assuage investors.

In each specification, the coefficients estimated for the real return on loans are positive and significant for both size groups of banks, even when controlling separately for the overall level of interest rates as in specification 1 . The positive coefficient on the real rate of return on loans can be interpreted to mean that banks with opportunities to make profitable loans are willing to pay higher rates to attract deposits in order to fund them. Moreover, for small banks, the long-run effect of this variable is estimated to be not statistically significantly different from unity, which is intuitively appealing because it implies that, at the margin, the cost of funding is approximately equal to the benefit of lending activity, suggesting an efficient allocation of resources. ${ }^{20}$

In all but one case, the coefficient on the deposit rate of the competing banking sector is positive (and generally statistically significant), reflecting the fact that deposits at the two types of banks are substitutes. If large banks had gained a significant amount of pricing power through mergers and acquisitions, then we would expect the coefficient on this variable in the small bank equation to be larger and more significant than its counterpart in the large bank equation. However, there is no evidence that small banks' deposit rates are tied more strongly to rates at large banks than vice versa. In two of the three specifications, the long-run effects are estimated to be not statistically different from one another, while in specification 3 , the most parsimonious, large bank rates are estimated to be more sensitive to small bank rates than small bank rates are to

\footnotetext{
${ }^{20}$ In the presence of a lagged dependent variable the magnitude of the long run effect of a change in an independent variable on the dependent variable is calculated as: coefficient on independent variable / $(1-$ coefficient on the lagged dependent variable), or in the example of specification 3 for small banks in Table 3: 1.057 / (1 - 0.271).
} 
large bank rates.

The ratio of uninsured deposits to total deposits is positive in each of the specifications for total deposits at large and small banks, and generally highly significant as well. This is the expected result because uninsured deposits are presumably more expensive to acquire than insured, and a higher fraction of uninsured deposits implies a greater degree of risk to each of the uninsured depositors. Thus, these results do suggest that the declining real value of deposit insurance, which would tend to cause the ratio of uninsured deposits to total deposits to rise, has reduced the subsidy that this coverage provides and raised the cost of funding assets at both large and small banks.

This result is also consistent with the arbitrage model presented above, because the period over which the coefficients are estimated includes the early 1990s when the bank failure rate was elevated. We attempted to estimate the equation over the latter period only, to test whether the coefficient on the uninsured share of deposits became smaller during the mid and late 1990s. However, due to the small sample size, the results were inconclusive.

Moreover, the long-run effect of the uninsured share of deposits is estimated to be somewhat larger at small banks than at large banks. This is consistent with the view that deposit insurance is more valuable to small than large banks owing to differences in perceived risk. It may also reflect the greater reliance on deposits at small banks, since large banks can more easily turn to other liabilities when the price of deposit funding becomes less attractive. In addition, small banks generally have a more limited customer base from which to attract deposits, which would 
force them to boost their offering rates relatively more than large banks to attract a given dollar amount of deposits.

The results also suggest that competition from nonbank financial institutions, measured by the share of total deposits and deposit-like instruments held by money market mutual funds and thrifts increases the cost of deposits for small banks. At large banks, by contrast, there is no evidence that competition for deposits from nonbanks led to increased interest costs; indeed in some specifications the coefficient on this variable is negative and statistically significant. Thus, as one might expect, the evidence suggests that growth of nonbank financial institutions present greater competitive challenges for small banks, owing to their greater reliance on deposits generally and retail deposits in particular, than for large banks.

In addition to the above variables, some other potential determinants of deposit rates were tested. The real rate on three-month Treasury bills was included as a proxy variable for the rate of return available on alternative safe and fairly liquid investments. It was insignificant. The unemployment rate was included as a cyclical variable to test the assumption that the perceived risk of bank failure increases during economic downturns, tending to push up rates on uninsured deposits, and decreases during economic upturns, tending to hold down deposit rates. This hypothesis was borne out by the data, as the coefficient on the unemployment rate is always positive and generally significant. However, there was no statistically significant difference between the values of the coefficients for large and small banks, suggesting that once balance sheet health is controlled for, the perceived riskiness of banks during cyclical economic fluctuations does not vary much by bank size. 
Another cyclical variable, the real growth rate of GDP, was included in all three specifications. While this variable would also likely capture some of the changes in the perceived riskiness of bank size groups at different points in the business cycle, it also serves as a proxy variable for deposit demand. In either case, the expected coefficient would be negative. However, when it is entered into the regressions along with the unemployment rate, the coefficient might be interpreted to reflect mainly the effect of money demand. In fact, higher growth rates of GDP are associated with lower deposit rates in each of the regression specifications, even when the unemployment rate is also included, although the absolute value of the effect is small and sometimes insignificant at traditional confidence levels.

3. What Drove the Increase in the Interest Rate Spread?

As detailed in the first row of Table 4, the spread of the average interest rate on deposits at small banks compared with large banks increased from 29 basis points during the 1990-92 period to 110 basis points during the $1998-2000$ period. The remaining rows of the table show the estimated change in this spread resulting from changes in the independent variables between those two periods, based on the regression results presented in table 2. Although the sum of the estimated effects accounts for more than the total change over the period, the relative magnitudes of the implied changes are still instructive.

The estimated long-run effects of the leverage ratio are not generally significantly different at small and large banks. However, at large banks, the leverage ratio increased 2.3 percentage points (from an average of 5.7 percent during the 1990-1992 period to an average of 8.0 percent 
from 1998 through 2000), while at small banks the same ratio increased only 1.6 percentage points (from 8.7 percent to 10.3 percent) over the same period. According to the point estimates of the long-run effects for capital ratios in the specification in column 3 of Table 3 , replicated in columns 4 and 5 of Table 4, the greater improvement in capital ratios at large compared with small banks during the decade added about 40 basis points to the spread between small bank deposit rates and large bank deposit rates, ceteris paribus.

The average real effective loan rates increased by approximately the same amount at large and small banks between the 1990-1992 period and the 1998-2000 period. In this specification, however, the long-run effect of return on loans on deposit rates is estimated to be almost three times larger for small banks than for large banks. As a result, our estimates suggest that changes in the average effective loan rate contributed about 80 basis points, all else equal, to the total widening in deposit interest rate spreads at small relative to large banks between 1990 and 2000.

Banks faced a fair amount of additional competition from money market mutual funds, where the share of deposit-like products increased from 11 percent at the beginning of the 1990s to about 19 percent at the end of the decade. However, that increased share of deposit products at money market funds was more than offset by a 10 percentage point decline in the share of deposits held by thrift institutions, from 35 percent to 25 percent. The 2 percentage point decline in deposit share when both types of competing institutions are combined results in an estimated 35 basis point decline in the spread of deposit rates at small banks relative to large banks over the 1990s.

The long-run effect on the average interest rate paid on all deposits of a 1 percentage point 
increase in the share of uninsured deposits is 4.4 basis points higher at small banks than at large banks. Between the early 1990s and the end of the decade, the uninsured share of deposits has risen, on average, by about 6 percentage points at small banks, while edging up just 1.5 percentage points at large banks. Thus, holding everything else equal, the cumulative effect of the increased reliance on uninsured deposits at both small and large banks added about 40 basis points to the spread between the average interest rates paid on deposits at small banks over that at large banks.

The implication for the estimated coefficients on the share of uninsured deposits for what an increase in the deposit insurance ceiling would mean for offering rates at small compared with large banks is unclear. As noted, the estimated coefficient is greater for small banks. However, the effect of, say, a doubling of deposit insurance to $\$ 200.000$ on the volume of insured deposits depends on the share of deposits issued in denominations between $\$ 100,000$ and $\$ 200,000$.

Under the extreme assumption that each account of greater than $\$ 100,000$ contains more than $\$ 200,000$ at both large and small banks, the percentage of uninsured deposits at large banks would have fallen from about 36 percent to about 25 percent, and at small banks the share would fall from almost 18 percent to 4 percent. However, as noted earlier, the average value of deposits issued in denominations over $\$ 100,000$ was only $\$ 229,000$ at small banks compared with $\$ 425,000$ at large banks. Thus, the 14 percentage point decline in the share of uninsured deposits at small banks is likely a considerable overstatement, while the 11 percentage point decline at large banks may be somewhat less so. 


\section{Estimates for Deposit Rates, by Deposit Type}

Table 4 details the results of the regressions for each type of bank deposit—large time, small

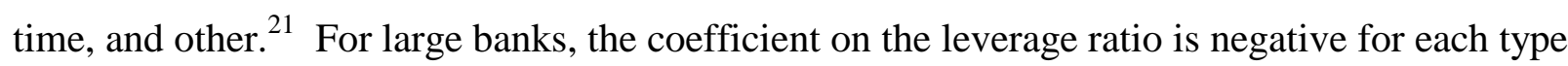
of deposit. As may be expected, the long-run effect of this variable is least statistically significant in the equation for small time deposits, which are by definition fully insured, and thus their payoff probabilities are least affected by the bank's capital position. By contrast, it is significant at traditional confidence levels in the "other deposits" category, where about 70 percent of the uninsured deposits at large banks are held, but is only marginally significant in the equation for large time deposits, which hold the remaining 30 percent of uninsured deposits at large banks. For small banks, however, the coefficient on this variable is never significant and the point estimates are positive in all three deposit categories, as was also the case for total deposits discussed above.

The coefficients on the real return on loans are positive and highly significant in the categories of deposits that are most often used as marginal funding sources, large and small time deposits. However, the long-run effects of these variables are not significantly larger for small banks than for large banks, which is a bit unexpected given the greater reliance on deposits as a marginal funding source by small banks. Moreover, while large time deposits are often considered managed liabilities, the rates on small time deposits are estimated to be more sensitive to the return on loans than are rates on large time deposits for both bank size categories.

\footnotetext{
${ }^{21}$ As noted above, it is not possible to construct a series to control for changes in the maturity distribution of time deposits over the entire period studied. However, we did construct series to control for the fraction of large and small time deposits that had less than three months to maturity and the fraction that had between 3 months and 12 months to maturity over shorter time intervals. Including these series in several of the specifications did not materially affect the conclusions reached in this study. Additional results are available upon request.
} 
The coefficient on return on loans is insignificant in the other interest-bearing deposits equation for small banks, but at large banks the coefficient is significant and positive. Other deposits contain a mixture of savings deposits and interest-bearing checking (NOW) accounts, which have very sluggish interest rates, as well as money market deposit accounts where the interest rate is sensitive to market conditions. Other deposits at small banks are more concentrated in savings and NOW deposits, which suggests that they are not marginal funding sources for small banks. At large banks, by contrast, the vast majority of these funds are in money market deposit accounts, which they can apparently use as managed liabilities.

As expected, the coefficients on the uninsured share of deposits are generally positive. In the equation for small time deposits, the coefficient on this variable is positive but not statistically significant and fairly small at both bank groups. In addition, there is no significant difference in the estimated magnitude of the long-run effects on the pricing of small time deposits at small and large banks. Once again, this result is consistent with prior expectations; small depositors are unlikely to demand much of a risk premium because their funds are fully insured.

For small banks, the coefficients on the uninsured share of deposits are significant in the large time and other deposit categories. However, at large banks, the coefficients are insignificant in the equations for both of these types of deposits, where there are large amounts of uninsured funds, which could be construed as evidence that depositors act as if TBTF exists. Alternatively, the increase in deposit rates at large banks caused by declines in the real value of deposit insurance may be immaterial because large banks are already attracting large amounts of 
uninsured funds in other markets. That is, for any given decline in the real value of deposit insurance the added need for uninsured deposits at small banks is much larger, thus the resulting additional costs are more apparent in the regression model.

There is less evidence that the uninsured share of deposits impacted the spread between rates offered on large time deposits by small and large banks, because the difference in the magnitude of the estimated long-run effects in that deposit category is economically small and not statistically significant. In the equations for "other" interest-bearing deposits, however, the point estimates suggest that small banks may pay a premium over large bank rates of more than 10 basis points per 1 percentage point increase in the uninsured share of deposits. However, this difference is only marginally statistically significant.

The deposit offering rate at large banks is positive and significant in each of the three deposit type equations for small banks, and the deposit offering rate at small banks is significant in all but one of the large bank equations. Furthermore, the effects are estimated to be larger at small banks, although the difference in the long-run effects is only statistically significant in the equation for large time deposits. Nonetheless, these results are consistent with the notion that small banks tend to act as price takers in the deposit market, particularly in those markets with significant amounts of uninsured funds.

\section{Summary and Conclusions}

Consolidation within the banking industry over the last decade and a half has increased the size and scope of large banks and produced some banks that are perhaps large enough to fuel 
depositors' perceptions that they could be "too big to fail." In conjunction with the decline in the real value of deposit insurance since 1980, the return to heath of large banks after the early 1990s, and the continued increase in the assets of nonbank financial companies, the competitive position of small banks would appear to have been seriously challenged.

Merger-adjusted Call Report data, however, indicate that small banks prospered throughout the 1990s. Small bank assets have grown at rates exceeding their large bank competitors and they have maintained historically high levels of profitability, even as the average cost of deposits at small banks relative to large banks has increased over the past decade. The results of this paper shed some light on why small banks have remained so competitive.

First, we developed an arbitrage model of deposit pricing with risk-averse investors who choose whether to deposit uninsured funds in a "Too Big To Fail" institution or a smaller bank on the basis of deposit rate spreads. This model indicates that when the probability of failure for small banks is at the low levels that have prevailed since the early 1990s, then the subsidy provided by deposit insurance and TBTF is tiny. Although the model suggests that these subsidies become large when the probability of failure reaches elevated levels, it is precisely at those times when deposit insurance creates the greatest degree of moral hazard. That is, it allows a troubled institution to continue to attract insured funding that is subsequently invested in risky assets with the hope that the profits earned on the new investments will return the troubled bank to health, but also creating a larger loss for the bank insurance fund if the bank does not recover.

Second, regression analysis suggests that the increased cost of deposits at small banks relative to 
large banks during the 1990s stemmed mostly from small banks' need for deposits to fund their aggressive and apparently more profitable loan growth. ${ }^{22}$ Another reason deposit rates may have climbed at small banks relative to large is the improved health of the large bank sector, reflected in their much-improved capital ratios, during the 1990s. Competition from nonbank financial firms is also estimated to have a statistically significant impact on the deposit offering rates at small banks, although it is generally not estimated to affect the deposit rates at large banks. However, the decline in the assets of the thrift industry more than offset the increased assets of money market mutual funds. Thus, on balance, the reduced competition from these sources held down deposit rates at small banks over the period studied.

The growing share of uninsured deposits (which was used as a proxy variable for the decline in the real value of deposit insurance over the 1988 to 2000 period) also had a positive and statistically significant effect on the price of deposits at both large and small banks. Moreover, the regression analysis suggests that the increase in the share of uninsured deposits had a larger effect on small banks than on large banks, particularly for savings and interest-bearing transaction deposits. The arbitrage model suggests that these coefficient estimates could be influenced by the high rate of bank failures in the early 1990s; however, a statistical test of that hypothesis was inconclusive. This factor is estimated to account for roughly the same overall increase the deposit rate spread between small and large banks as the improved balance sheet health at large banks, and about half of the increase owing to the change in their average return on loans.

\footnotetext{
${ }^{22}$ The increased rate of return on loans at small banks is an interesting topic for further research.
} 


\section{REFERENCES}

Akhavein, Jalal, Allen Berger, and David Humphrey, "The Effects of Megamergers on Efficiency and Prices: Evidence from a Bank Profit Function" Review of Industrial Organization, vol. 12 (1997), pp. 95-139

Angbazo, Lazarus and Anthony Saunders, "The Effect of TBTF Deregulation on Bank Cost of Funds." The Wharton School. Working Paper 97-25.

Black, Harold A., M. Cary Collins, Breck L. Robinson, and Robert L. Schweitzer, "Changes in Market Perception of Riskiness: The Case of Too-Big-To-Fail.” The Journal of Financial Research, XX:3 (Fall 1997) pp.389-406.

Bassett, William F. and Egon Zakrajsek, "Profits and Balance Sheet Developments at U.S. Commercial Banks in 2000," Federal Reserve Bulletin, vol. 88 (June 2001), pp. 367-93.

Bassett, William F. and Thomas Brady, "," Federal Reserve Bulletin, vol. 88 (November 2001), pp. 367-93.

Berger, Allen N., Anil K. Kashap, and Joseph M. Scalise, "The Transformation of the U.S. Banking Industry: What a Long, Strange Trip Its Been.” Brookings Papers on Economic Activity 1995:2 (1995), pp. 55-201.

D'Arista, Jane W. and Tom Schlesinger, "The Parallel Banking System." Transforming the U.S. financial system: Equity and efficiency for the 21 st century. Armonk, N.Y. and London: Sharpe 1993. pp. 157-99.

Demsetz, Rebecca, and Philip Strahan, "Diversification, Size, and Risk at Bank Holding Companies" Journal of Money Credit and Banking, vol. 29 (August 1997), pp. 300-13.

Dynan, Karen, Kathleen Johnson, and Sam Slowinski, "Survey of Finance Companies, 2000" Federal Reserve Bulletin, January 2002, pp. 1-13.

English, William and William Nelson, "Profits and Balance Sheet Developments at Commercial Banks in 1997." Federal Reserve Bulletin vol. 84 (June 1997), p. 408.

Federal Deposit Insurance Corporation, "Federal Deposit Insurance Corporation Options Paper." August 2000.

Greene, William H., Econometric Analysis. Prentice-Hall Inc.: New Jersey. 1993. p. 560.

Greenspan, Alan, Chairman, Board of Governors of the Federal Reserve System. "The Evolution of Bank Supervision." Speech to the American Bankers Association. Board of Governors of the 
Federal Reserve System. October 11, 1999.

"The Financial Safety Net" Speech at the 37th Annual Conference on Bank Structure and Competition of the Federal Reserve Bank of Chicago, Chicago, Illinois. May 10, 2001.

Independent Community Bankers of America, "Federal Deposit Insurance: Time for Reform and Increased Coverage.” Special Report. Fall 2000.

O'Hara, Maureen and Wayne Shaw, "Deposit Insurance and Wealth Effects: The value of being 'Too Big to Fail'." Journal of Finance 45:5, (December 1990) pp. 1587-1600.

Nakamura, Leonard I., "Small Borrowers and the Survival of the Small Bank: Is Mouse Bank Mighty or Mickey?" Federal Reserve Bank of Philadelphia Business Review. (NovemberDecember 1994) pp. 3-15.

Peristiani, Stavros, "Do Mergers Improve the X-Efficiency and Scale Efficiency of U.S. Banks? Evidence from the 1980s." Journal of Money Credit and Banking, 29:3 (August 1997) pp.32637.

Pilloff, Steven J. and Stephen A. Rhoades, "Do Large, Diversified Banking Organizations Have Competitive Advantages?" Review of Industrial Organization, 16:3, May 2000, pp. 287-302.

Rhoades, Stephen A. "A Summary of Merger Performance Studies in Banking, 1980-1993, and an Assessment of the 'Operating Performance' and 'Event Studies' Methodologies." System Staff Study No. 167, Board of Governors of the Federal Reserve, 1994.

Thompson, James B., "Who Benefits from Increasing the Federal Deposit Insurance Limit?" Economic Commentary. Federal Reserve Bank of Cleveland. November 2001. 


\section{Real Value of Deposit Insurance}

Value of Deposit Insurance

Quarterly

Nominal value

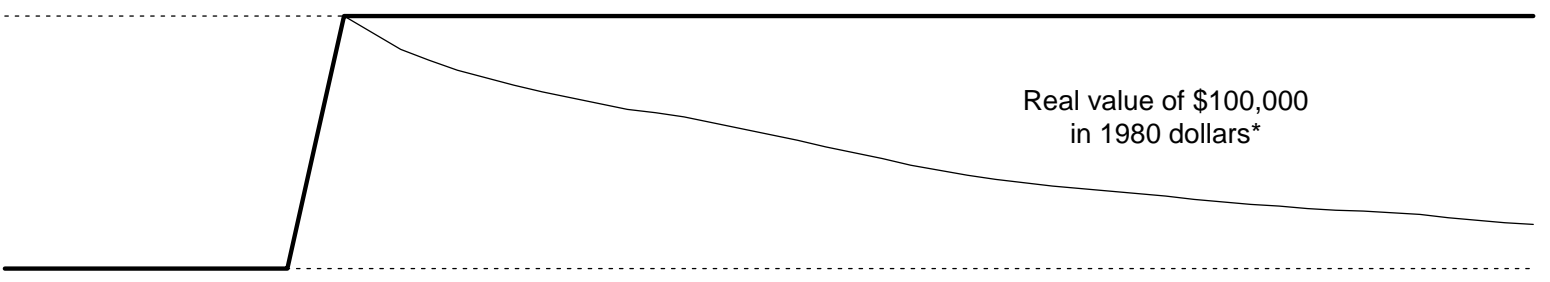

100

50

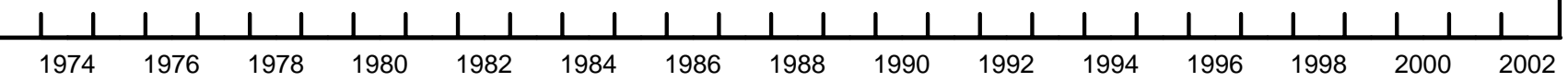

*Using the personal consumption expenditures implicit price deflator. 


\section{Industry Concentration}

\section{Share of Industry Assets}

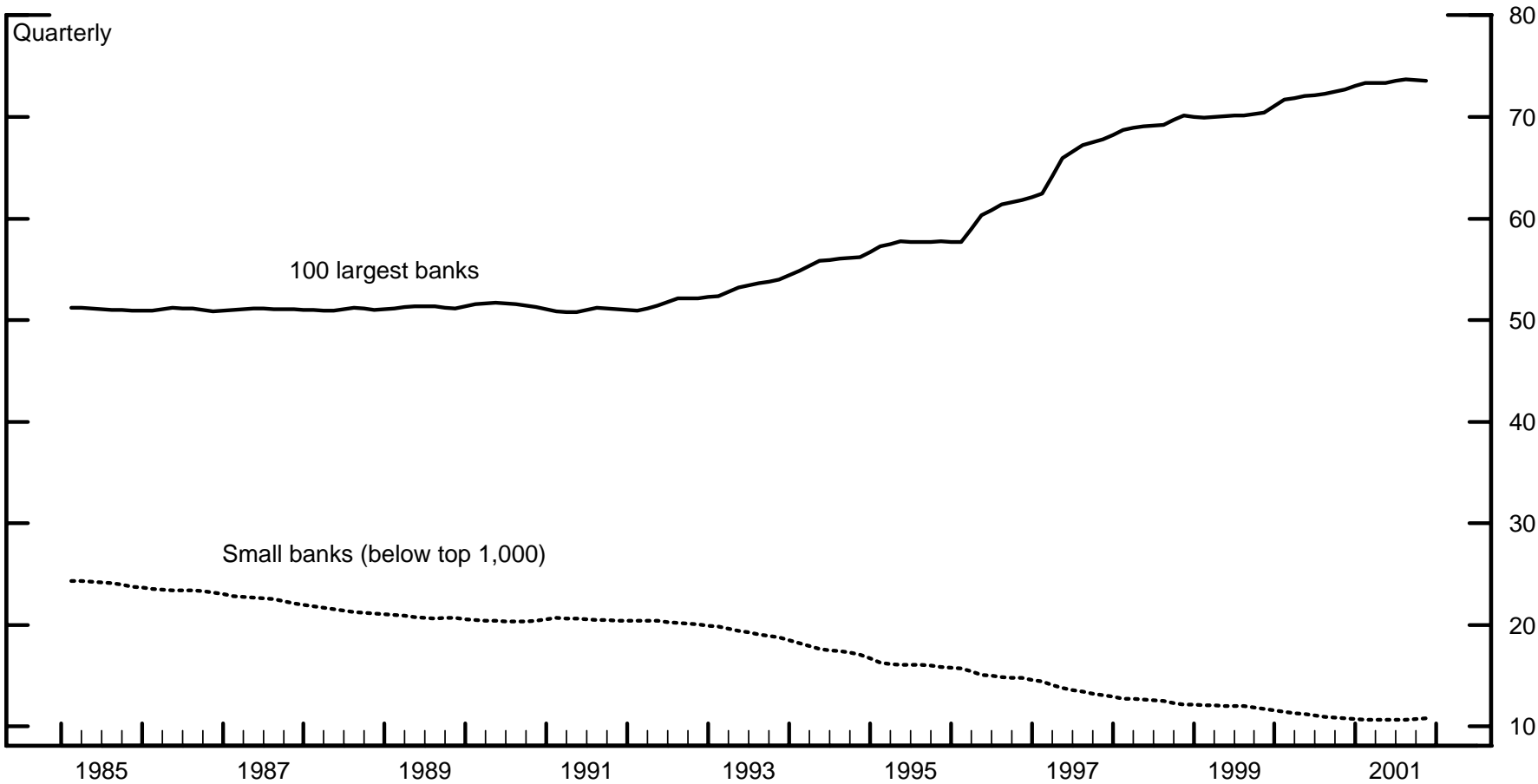

Number of Banks

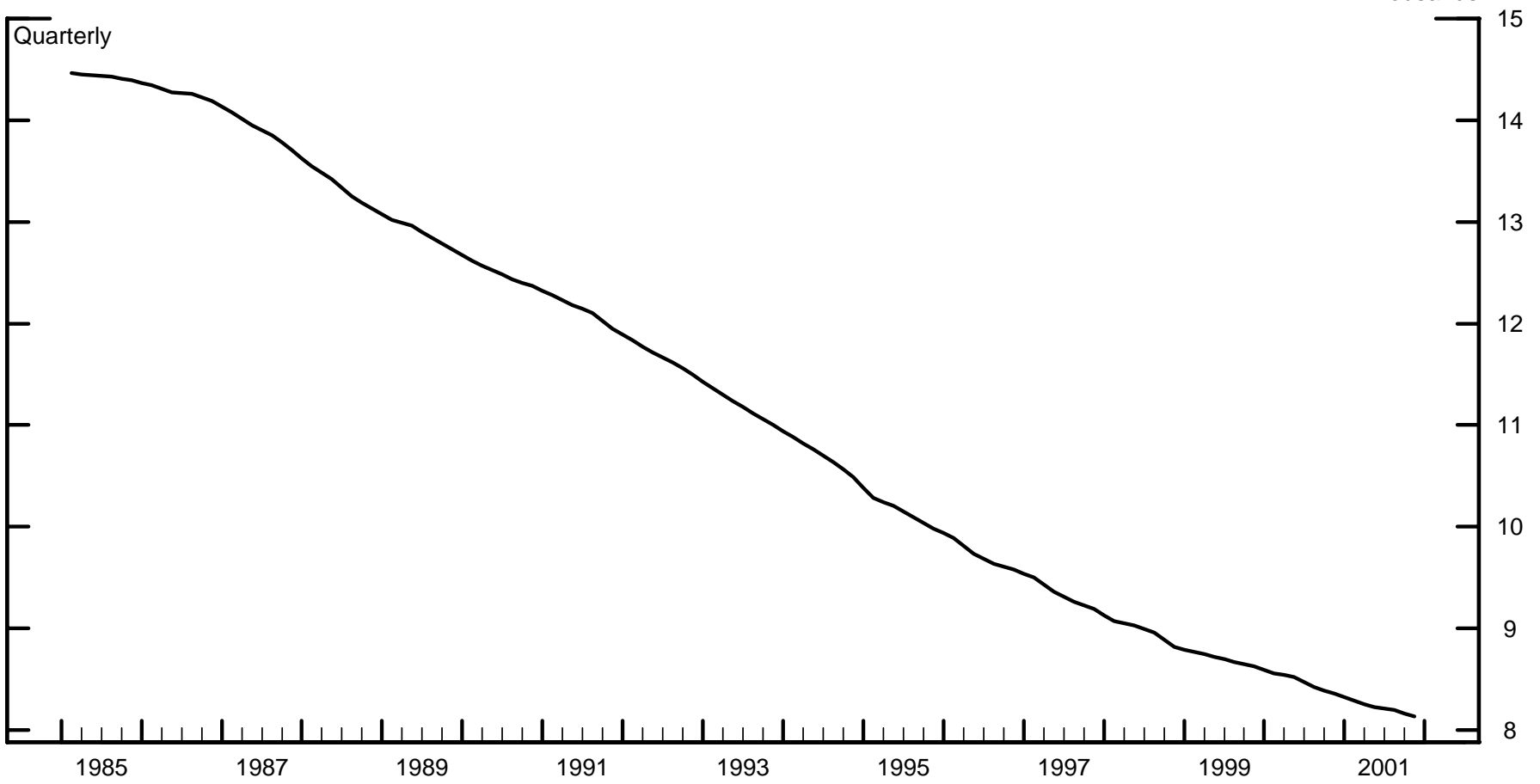




\section{Measures of Balance Sheet Health}

\section{Delinquency Rates}

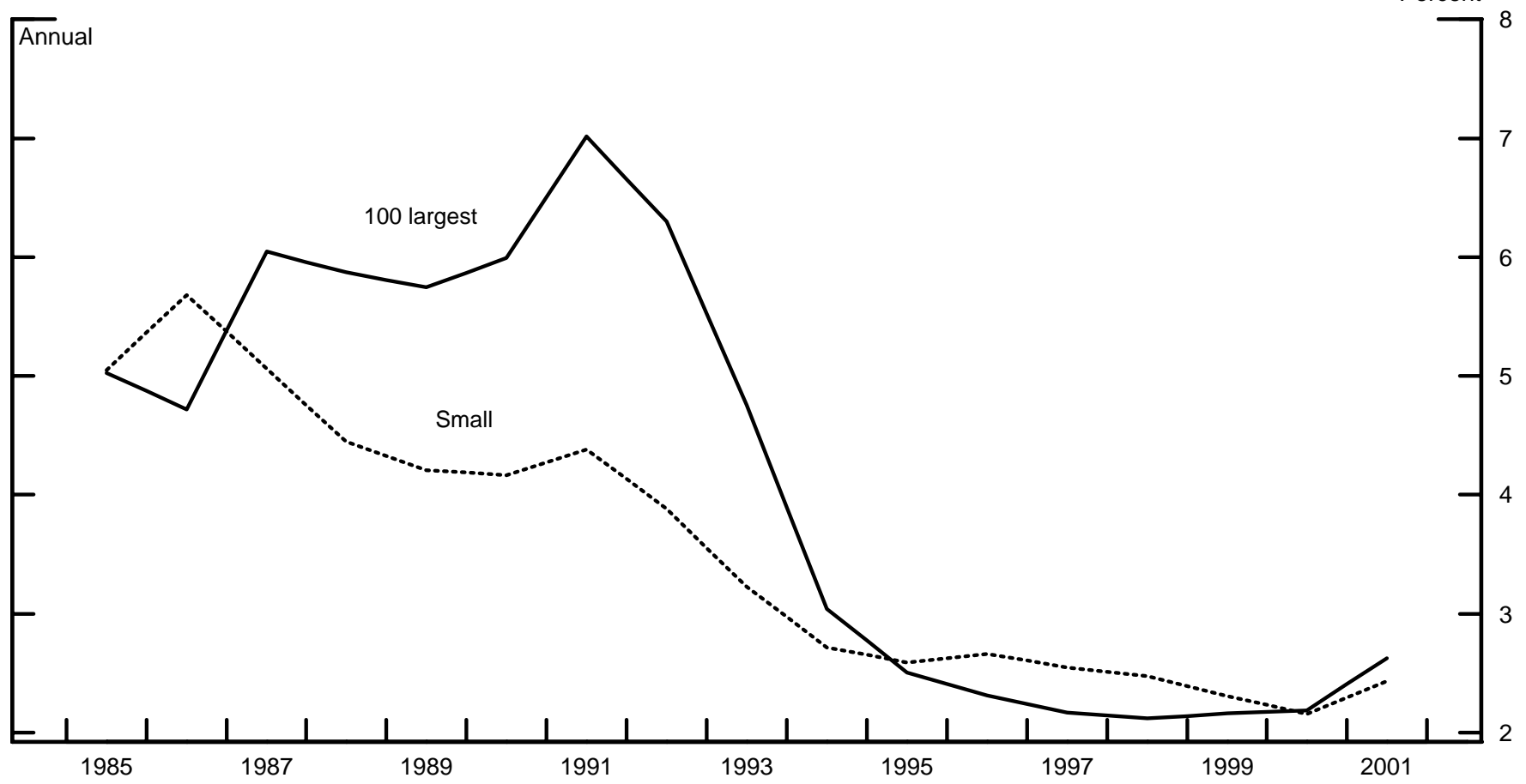

Equity to Assets Ratio

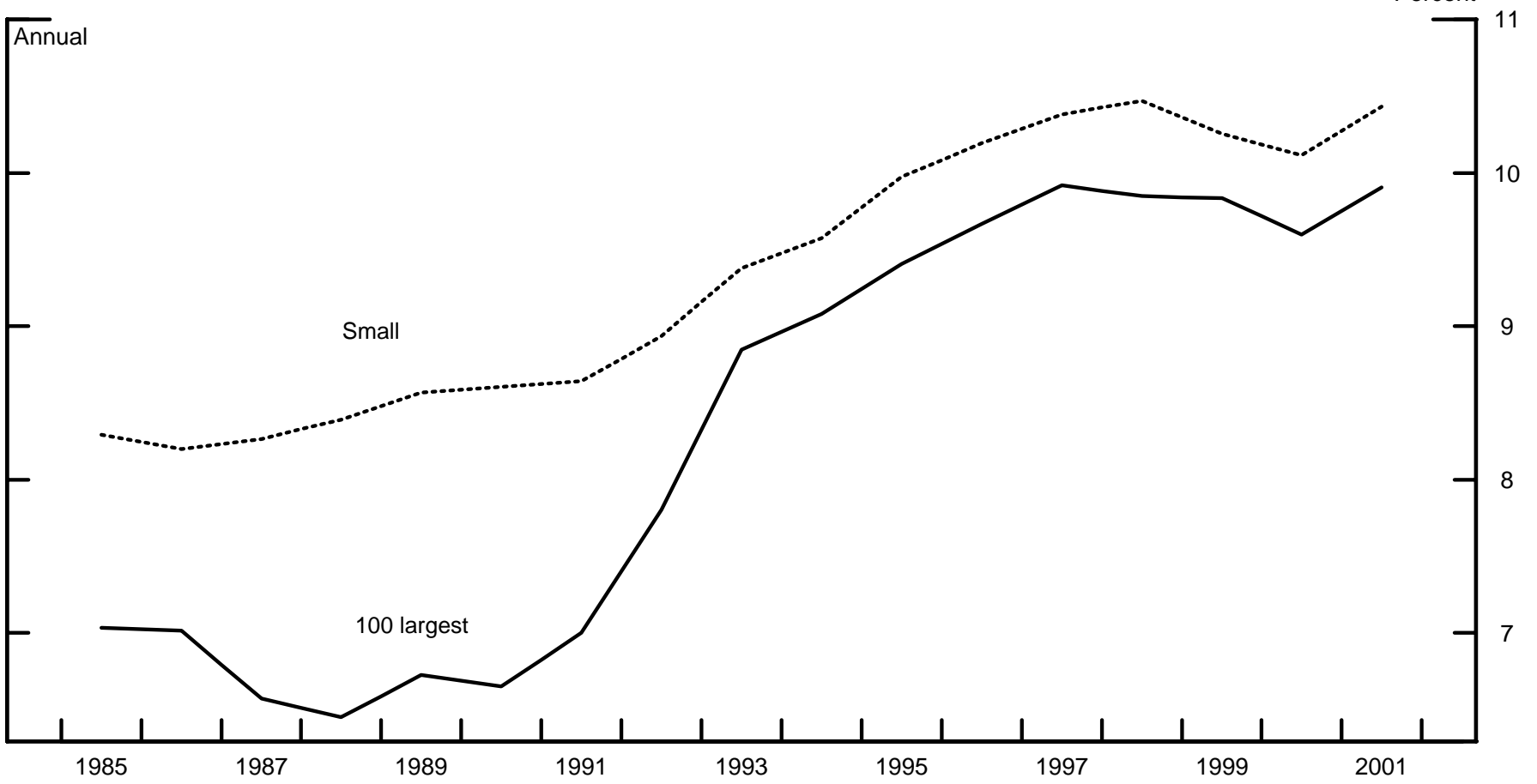




\section{Asset and Deposit Growth*}

Growth of Domestic Assets

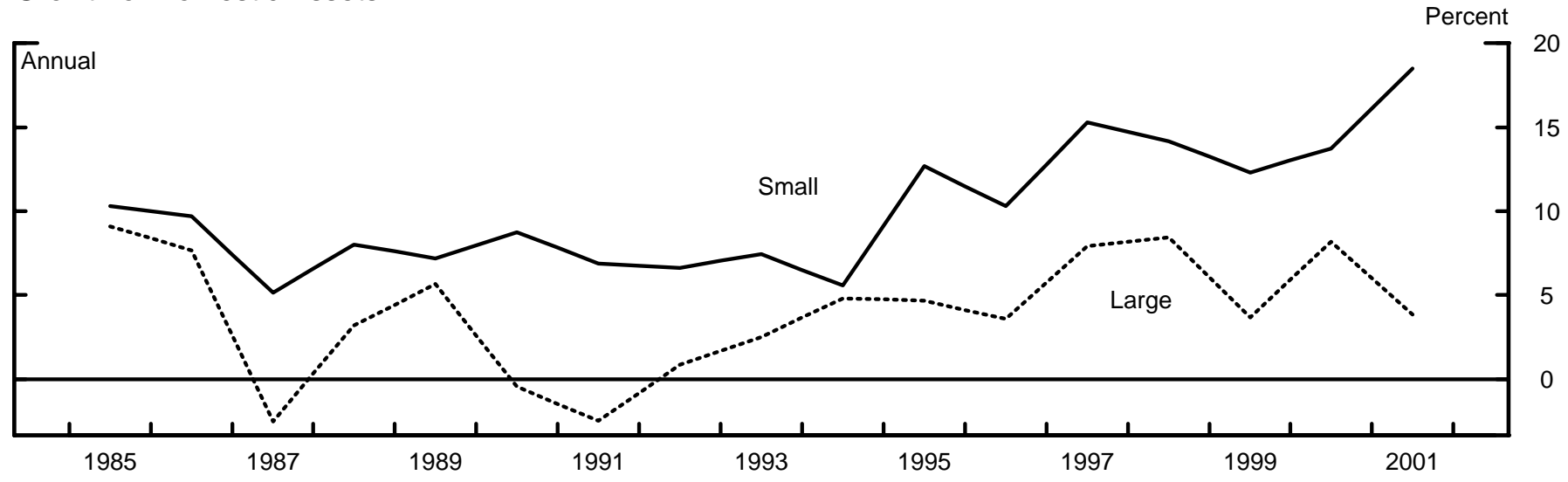

Growth of Total Deposits

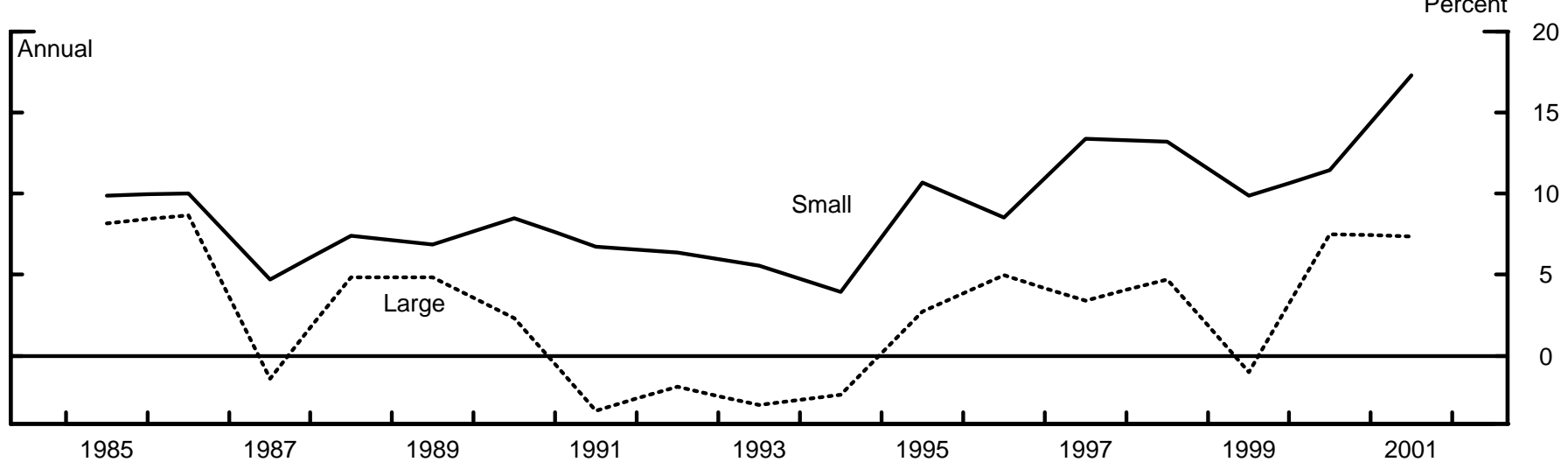

Growth of Uninsured Deposits

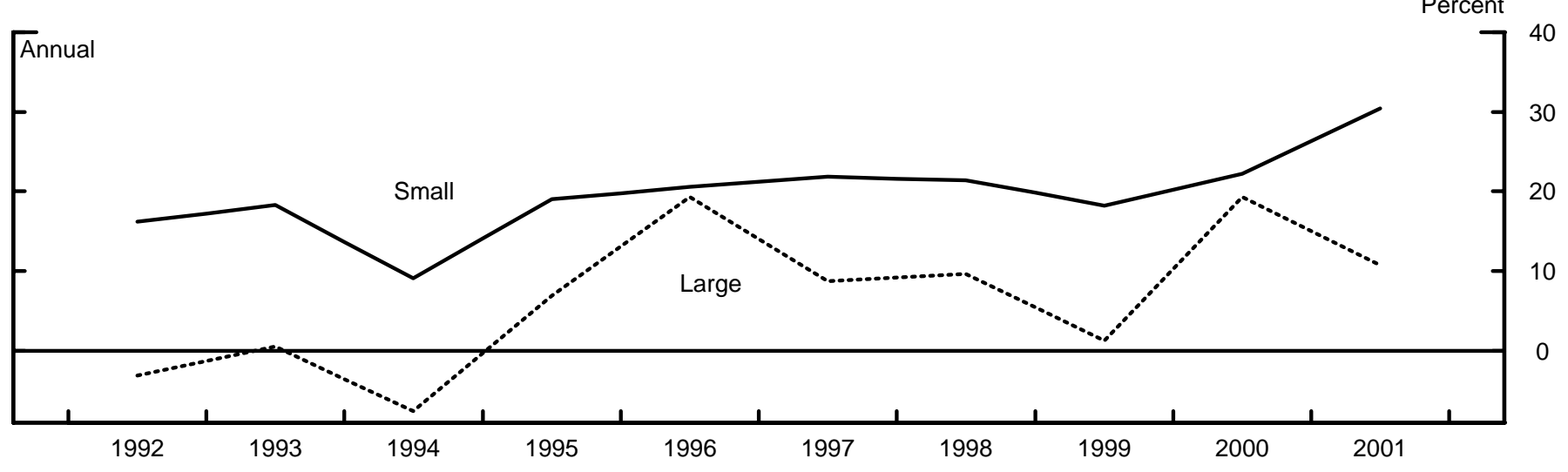

${ }^{*}$ Growth rates are adjusted for the effects of mergers. 


\section{Relative Deposit Rates and Relative Deposit Growth* (small to large)}

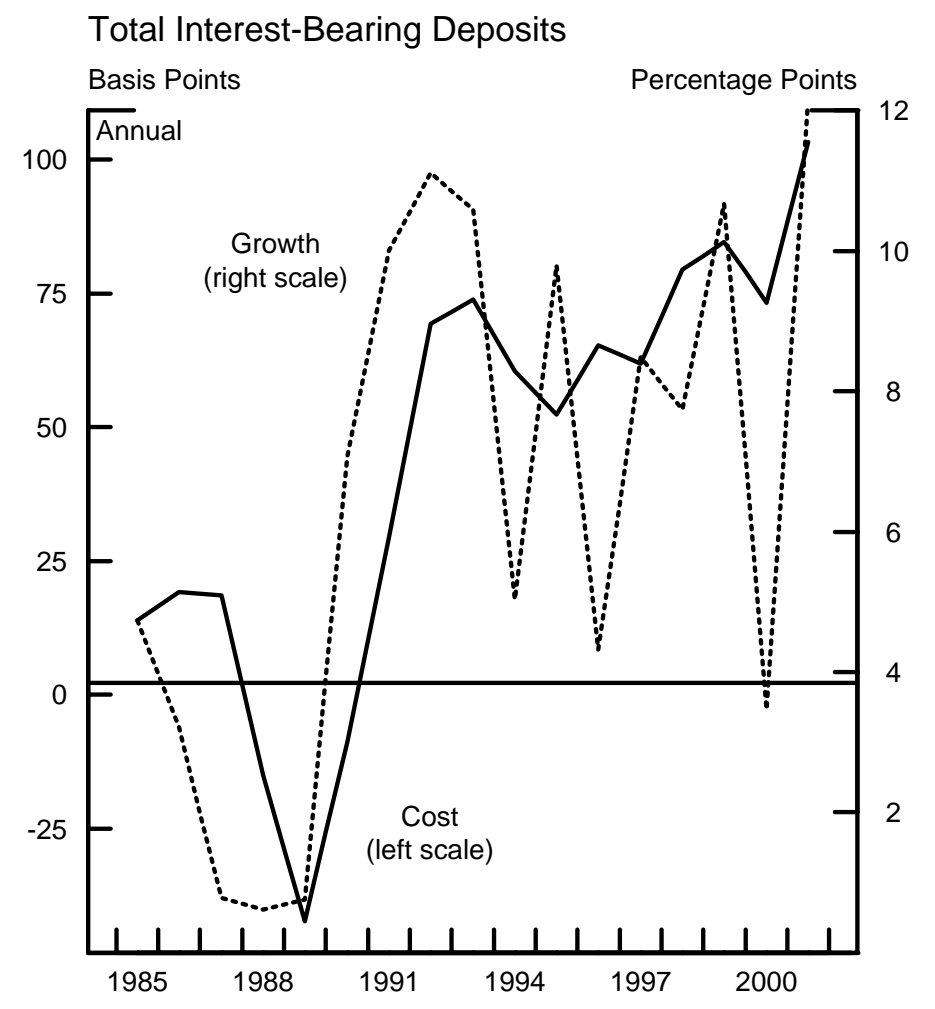

Small Time Deposits
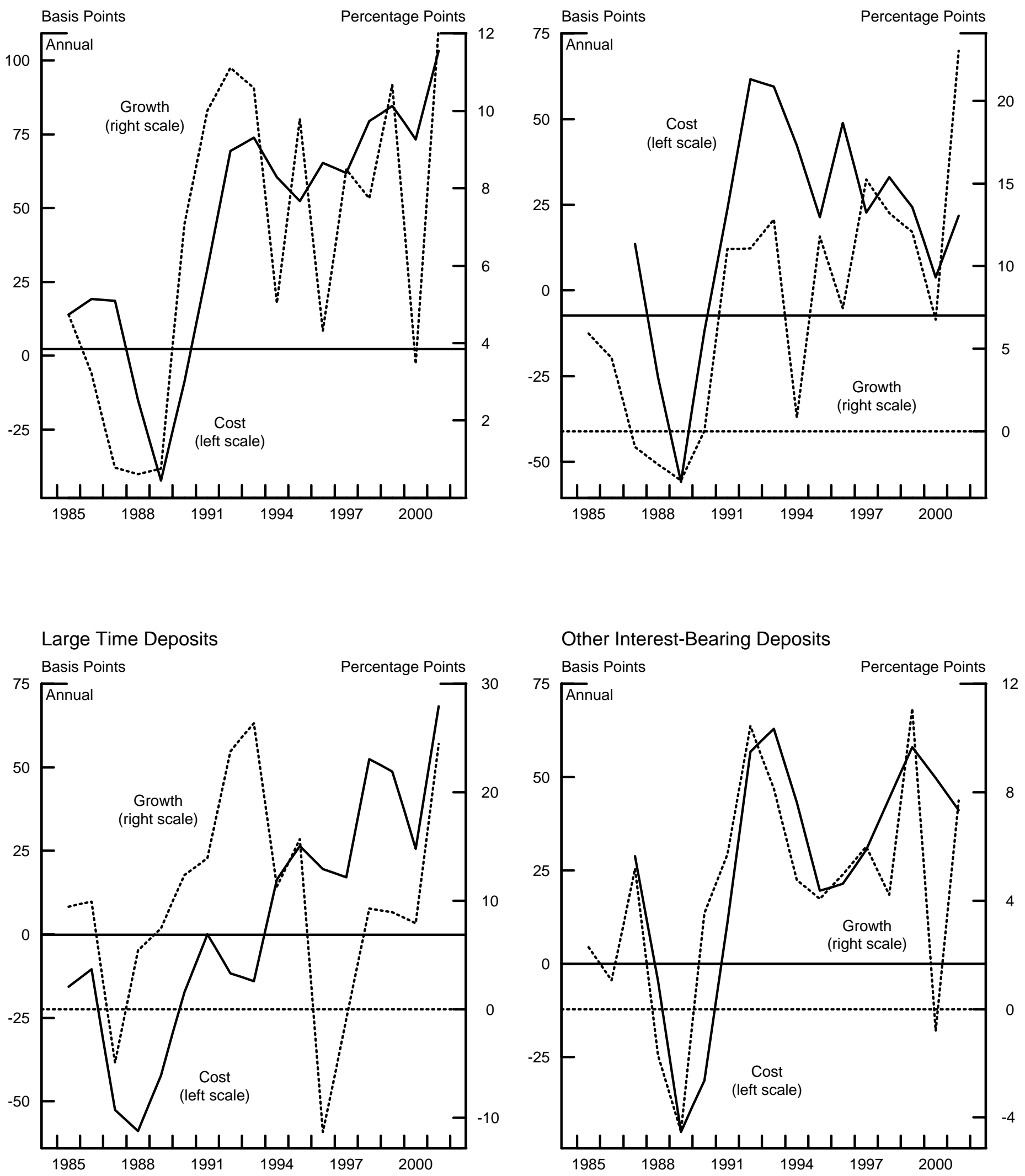

Other Interest-Bearing Deposits

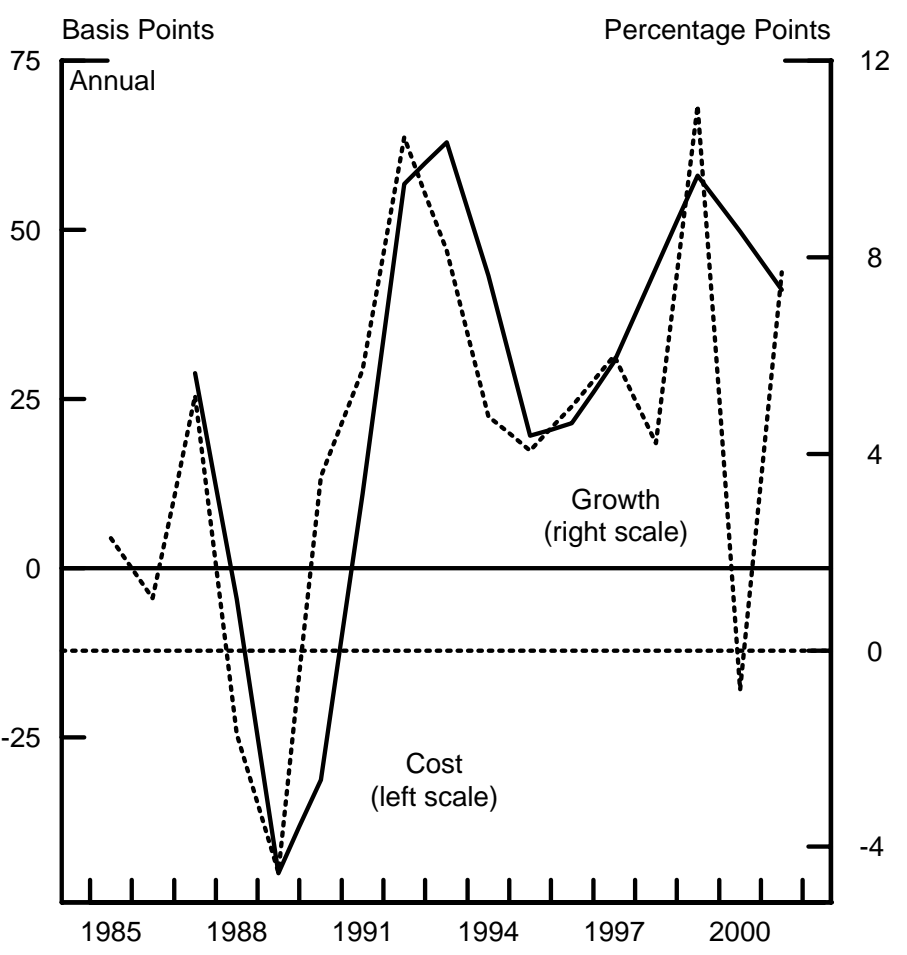

*Growth and deposit rates are adjusted for the effects of mergers. 


\section{Profitability}
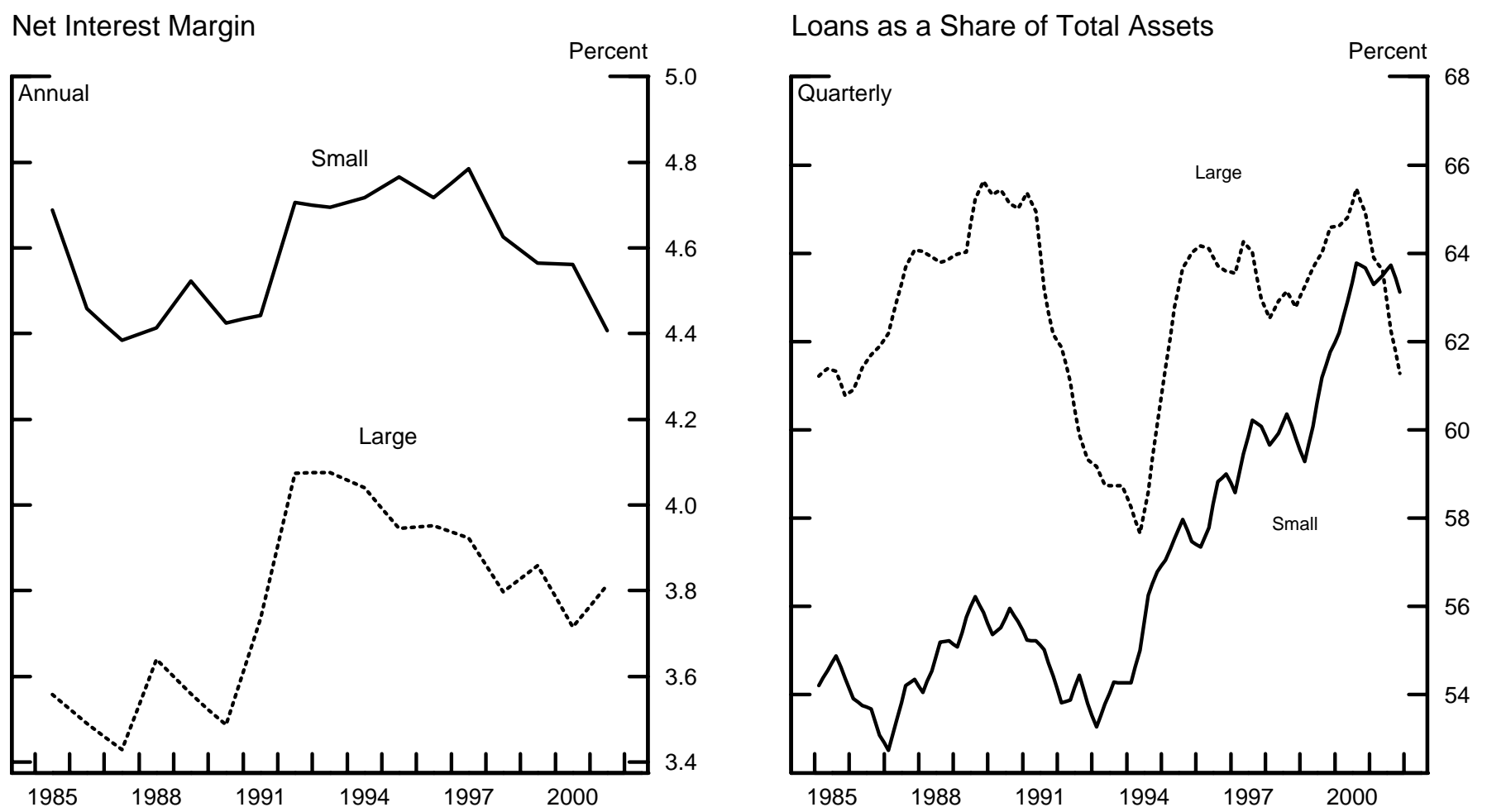

Return on Equity

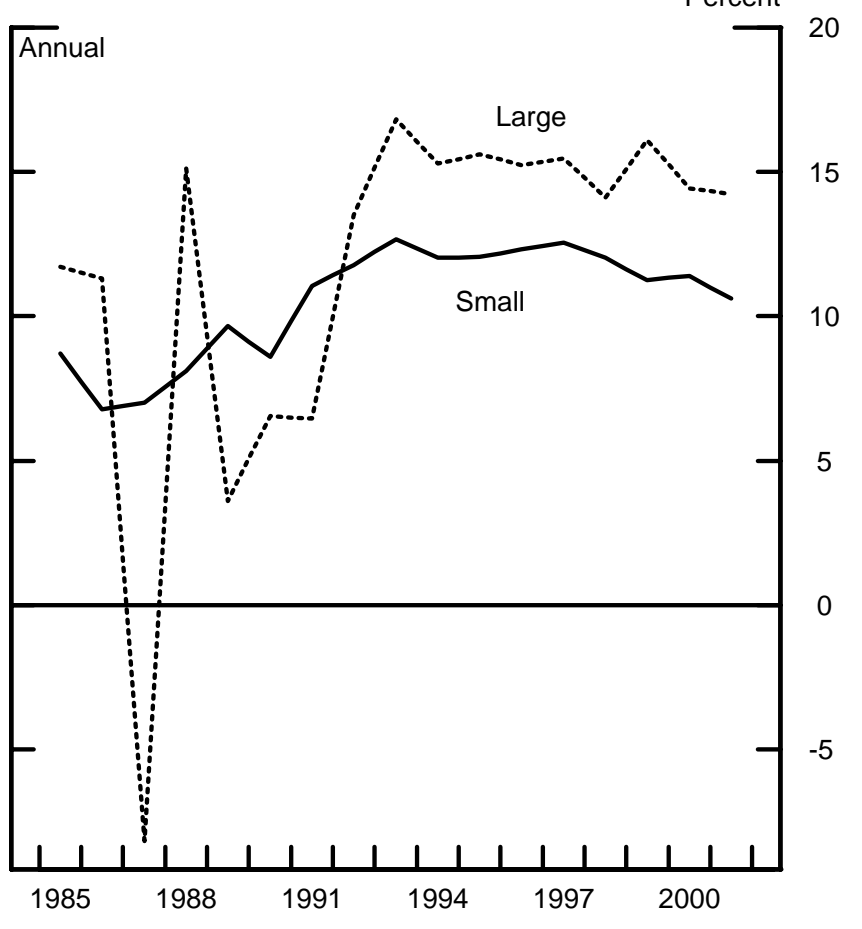

Return on Assets

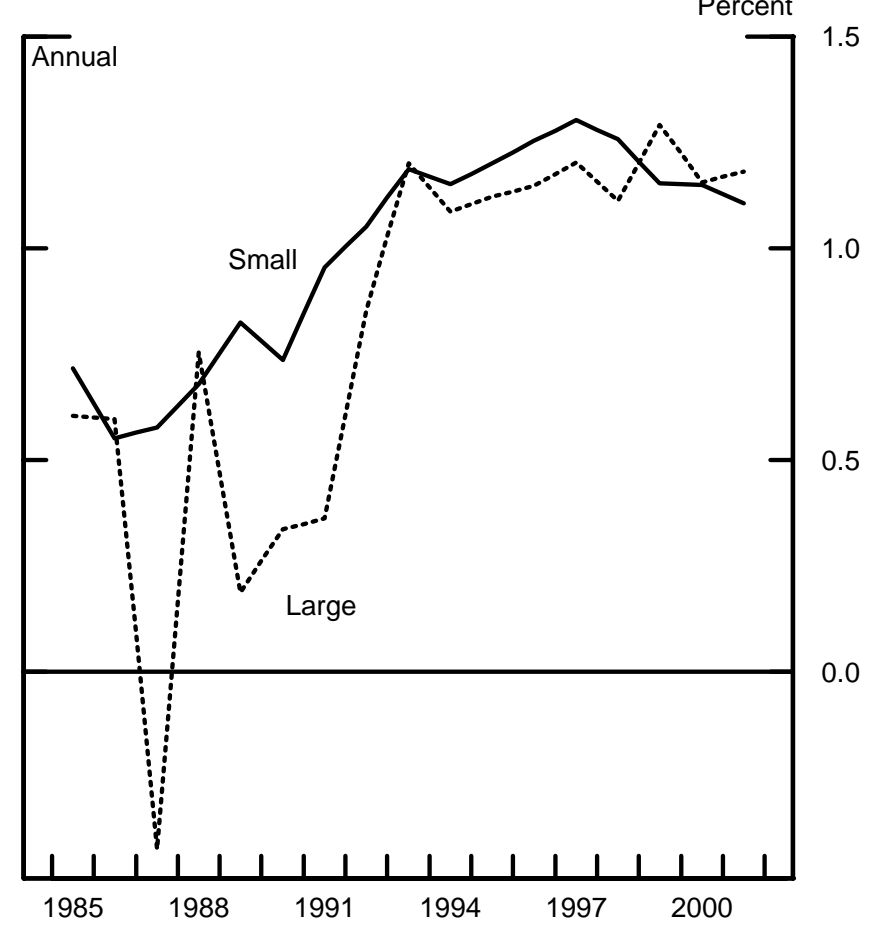


Table 1

Composition of Funding at Commercial Banks

(Share of Total Domestic Assets)

\begin{tabular}{|c|c|c|c|c|c|c|}
\hline & \multicolumn{3}{|c|}{ Large } & \multicolumn{3}{|c|}{ Small } \\
\hline & 1987 & 1992 & 2000 & 1987 & 1992 & 2000 \\
\hline Total deposits & 66.1 & 67.3 & 56.3 & 88.5 & 87.8 & 83.4 \\
\hline \multicolumn{7}{|l|}{ by account type: } \\
\hline Large time & 13.7 & 7.0 & 8.2 & 11.2 & 7.9 & 13.0 \\
\hline Small time & 10.1 & 13.4 & 10.0 & 29.9 & 31.5 & 28.5 \\
\hline Other interest bearing & 22.7 & 29.2 & 24.7 & 33.3 & 35.7 & 29.1 \\
\hline Non interest bearing & 19.7 & 17.8 & 13.4 & 14.1 & 12.8 & 12.9 \\
\hline \multicolumn{7}{|l|}{ by insured status: } \\
\hline Insured & n.a. & 46.3 & 35.8 & n.a. & 77.9 & 68.6 \\
\hline Uninsured & n.a. & 21.0 & 20.5 & n.a. & 10.0 & 14.8 \\
\hline FHLB advances & n.a. & n.a. & 2.4 & n.a. & n.a. & 3.1 \\
\hline Other liabilities & 29.2 & 26.0 & 33.2 & 3.2 & 3.1 & 3.2 \\
\hline Equity capital & 4.7 & 6.7 & 8.1 & 8.3 & 9.1 & 10.3 \\
\hline \multicolumn{7}{|c|}{ Memo: Deposit accounts $\$ 100,000$ or more } \\
\hline Average size $(\$ 1,000)$ & n.a. & 440 & 425 & n.a. & 209 & 229 \\
\hline Large time deposits as a share of total & n.a. & 29.9 & 31.1 & n.a. & 45.3 & 49.0 \\
\hline
\end{tabular}

n.a. - not available 
Table 2

Pricing of Large Time Deposits with Risk Averse Investors ${ }^{1}$

(Rate at Large Banks $=5.50$ percent, Amount of Deposit $=\$ 250,000, \mathrm{a}=1 / 4)$

\begin{tabular}{|c|c|c|c|c|c|c|}
\hline & $\mathrm{P}_{\mathrm{S}}$ & $\mathrm{B}_{\mathrm{L}}$ & $\mathrm{B}_{\mathrm{S}}$ & $\begin{array}{c}\text { Spread with } \\
\$ 100,000 \\
\text { Insurance } \\
\text { (Basis points) }\end{array}$ & $\begin{array}{c}\text { Spread with } \\
\$ 200,000 \\
\text { Insurance } \\
\text { (Basis points) }\end{array}$ & $\begin{array}{c}\text { Advantage of } \\
\text { Additional } \\
\text { Insurance } \\
\text { (Basis points) }\end{array}$ \\
\hline & (1) & (2) & (3) & (4) & (5) & (6) \\
\hline (1) & $0.025 \%$ & 0.00 & 0.00 & 7.1 & 1.8 & 5.3 \\
\hline (2) & $0.025 \%$ & 0.50 & 0.50 & 2.8 & 0.9 & 1.9 \\
\hline (3) & $0.025 \%$ & 0.75 & 0.25 & 5.8 & 1.6 & 4.2 \\
\hline (4) & $0.025 \%$ & 1.00 & 0.00 & 9.4 & 2.4 & 7.0 \\
\hline (5) & $0.25 \%$ & 0.00 & 0.00 & 46.1 & 18.1 & 28.0 \\
\hline (6) & $0.25 \%$ & 0.50 & 0.50 & 28.2 & 9.1 & 19.1 \\
\hline (7) & $0.25 \%$ & 0.75 & 0.25 & 57.7 & 16.3 & 41.4 \\
\hline (8) & $0.25 \%$ & 1.00 & 0.00 & 94.3 & 23.7 & 70.6 \\
\hline
\end{tabular}

1. Investors' preferences are represented by $\log$ utility (that is $U_{i}=\ln \left(Z_{i}\right), i=1,2$, corresponding to the non-failure and failure states of the world, respectively; $Z_{1}=\ln \left[\left(1+r_{j}\right)(y+x)\right]$ and $\left.Z_{2}=\ln \left(y+b_{j} x\right), j=L, S\right)$. 
Table 3

Instrumental Variable Regression Estimates in Levels

Dependent variable: real deposit rates

Parameter

\section{Large banks}

Constant

Leverage ratio

Real return on loans

Real GDP growth

Real T-bill

Deposit share of MMMF + thrifts

Notional value of derivatives / assets

Uninsured share of deposits

Real deposit rate at small banks

Real deposit rate at large banks (t-1)

Unemployment rate

Small banks

Constant

Leverage ratio

Real return on loans

Real GDP growth

Real T-bill

Deposit share of MMMF + thrifts

Uninsured share of deposits

Real deposit rate at large banks

Real deposit rate at small banks (t-1)

Unemployment rate
Specification 1

Estimate Std. error

$-1.364 \quad 1.441$

$-0.1170 .058 * *$

$0.4550 .133 * * *$

$-0.006 \quad 0.003 *$

$0.044 \quad 0.071$

$-0.037 \quad 0.028$

$-0.0010 .000 * *$

0.0290 .023

$0.5280 .146^{* * * *}$

$0.170 \quad 0.081 * *$

$0.101 \quad 0.088$

$-6.9122 .117 * * *$

$\begin{array}{ll}-0.085 & 0.058\end{array}$

$0.7440 .162 * * *$

$-0.0150 .005 * * *$

$\begin{array}{ll}-0.023 & 0.024\end{array}$

$0.0410 .024 *$

$0.0920 .016 * * *$

$0.2760 .155 *$

$0.1910 .057 * * *$

0.1230 .057 **
Specification 2

Estimate Std. error

$-3.8431 .510 * *$

$-0.2010 .055 * * *$

$0.6920 .074 * * *$

$\begin{array}{ll}-0.006 & 0.004\end{array}$

$-0.026 \quad 0.023$

$0.050 \quad 0.016^{* * *}$

$0.3380 .142 * *$

$0.224 \quad 0.094 * *$

$0.1830 .070 * *$

$-7.1111 .428 * * *$

$-0.045 \quad 0.064$

$0.6610 .157 * * *$

$-0.0110 .005^{* *}$

$0.0430 .017 * *$

$0.0960 .016 * * *$

$0.2990 .124 * *$

$0.208 \quad 0.045 * * *$

$0.154 \quad 0.048 * * *$
$-6.1241 .566 * * *$

Specification 3

Estimate Std. error

$2.8031 .306 * *$

$-0.5620 .088 * * *$

$0.6010 .072 * * *$

$\begin{array}{ll}-0.007 & 0.005\end{array}$

$-0.0910 .035^{* *}$

$0.0510 .021 * *$

$0.8050 .239 * * *$

$-0.185 \quad 0.171$

$-0.3050 .126^{* *}$

$1.0570 .261 * * *$

$-0.0220 .007 * * *$

$0.0520 .020 * *$

$0.0640 .014 * * *$

$\begin{array}{ll}-0.066 & 0.157\end{array}$

$0.2710 .039 * * *$

Estimation of difference between long-run effects on large-bank and small-bank variables ${ }^{1}$

\begin{tabular}{|c|c|c|c|c|c|c|}
\hline & Difference & $\underline{\text { Std. error }}$ & Difference & $\underline{\text { Std. error }}$ & Difference & $\underline{\text { Std. error }}$ \\
\hline Leverage ratio & 0.035 & 0.092 & 0.201 & $0.093 * *$ & 0.057 & 0.178 \\
\hline Real return on loans & 0.372 & 0.311 & -0.058 & 0.285 & 0.943 & $0.402 * *$ \\
\hline Deposit share of MMMF + thrifts & 0.095 & $0.049 *$ & 0.087 & $0.042 * *$ & 0.148 & $0.033 * * *$ \\
\hline Uninsured share of deposits & 0.079 & $0.034 * *$ & 0.057 & 0.034 & 0.044 & $0.025^{*}$ \\
\hline Real deposit rate at other bank group & -0.295 & 0.215 & -0.058 & 0.187 & -0.771 & $0.287 * *$ \\
\hline
\end{tabular}

Notes: Each variable is entered as the level of the underlying series, unless otherwise noted, and the instrument for each variable is the second lag of that variable. The equations were estimated jointly for small and large banks using Seemingly Unrelated Regression. Standard errors are corrected for autocorrelation and heteroskedasticity.

$*$ P-value $<0.10, * *$ p-value $<0.05$, *** p-value $<0.01$

${ }^{1}$ Small bank less large bank. Long-run effect $=$ coefficient $/(1-$ coefficient on lagged dependent variable $)$ 
Table 4

Implied Change in Spread of Deposit Rates at Small Banks Less Large Banks, 1990-92 to 1998-2000

\section{Average Values of Regression Variables}

Small Banks Small Banks Large Banks Large Banks $(1990-1992) \quad(1998-2000) \quad(1990-1992) \quad(1998-2000)$

Independent variables

Real gross return on loans

Uninsured share of deposits

Leverage (capital) ratio

Real GDP growth

Nonbank share of deposits

Competing banks' deposit rate

Memo: dependent variable

Real effective deposit rate

"Source: Table 3, specification 3.

$\begin{array}{rrrr}6.85 & 7.87 & 5.48 & 6.69 \\ 10.7 & 16.2 & 33.0 & 34.2 \\ 8.72 & 10.27 & 5.73 & 7.98 \\ 1.81 & 4.01 & 1.81 & 4.01 \\ 45.9 & 43.5 & 45.9 & 43.5 \\ 1.46 & 1.75 & 1.75 & 2.85 \\ & & & \\ 1.75 & 2.85 & 1.46 & 1.75\end{array}$

Estimated Long-Run Coefficients*

Small Banks Large Banks

$\begin{array}{rr}1.449 & 0.507 \\ 0.087 & 0.043 \\ -0.418 & -0.475 \\ -0.031 & -0.006 \\ 0.071 & -0.077 \\ -0.091 & 0.680\end{array}$

0.86 
Table 5

Instrumental Variable Regression Estimates in Levels, by Deposit Type

Dependent variable: interest rate on

Parameter

Large banks

Constant

Leverage ratio

Real return on loans

Real GDP growth

Deposit share of MMMF + thrifts

Uninsured share of deposits

Real deposit rate at small banks

Real deposit rate at large banks (t-1)

Small banks

Constant

Leverage ratio

Real return on loans

Real GDP growth

Deposit share of MMMF + thrifts

Uninsured share of deposits

Real deposit rate at large banks

Real deposit rate at small banks (t-1) $\underline{\text { Large time deposits }}$

$\underline{\text { Estimate }} \underline{\text { Std. error }}$

$-3.6142 .044 *$

$-0.1330 .094$

$0.3830 .094 * * *$

$0.002 \quad 0.013$

$0.064 \quad 0.046$

$0.016 \quad 0.024$

$0.6770 .181 * * *$

$-0.117 \quad 0.170$

$-0.583 \quad 1.761$

0.0370 .058

$0.2370 .114 * *$

$-0.0160 .008 *$

$-0.034 \quad 0.025$

$0.030 \quad 0.007 * * *$

$0.6510 .097 * * *$

$0.2630 .050 * * *$ $\underline{\text { Small time deposits }}$

Estimate $\underline{\text { Std. error }}$

$-1.936$

2.141

$\begin{array}{ll}-0.083 & 0.092\end{array}$

0.675

$0.187 * * *$

$-0.022$

$-0.028$

0.014

0.065

$0.033 \quad 0.031$

$0.043 \quad 0.344$

0.463

$0.184 * *$

$-5.061$

$0.932 * * *$

$0.031 \quad 0.090$

$0.6140 .107 * * *$

$-0.0160 .004 * * *$

$0.038 \quad 0.013 * * *$

$0.019 \quad 0.012$

$0.1410 .048 * * *$

$0.3650 .031 * * *$
Other deposits

Estimate $\underline{\text { Std. error }}$

$-0.598 \quad 2.057$

$-0.2350 .116 * *$

$0.4090 .141 * * *$

$-0.010 \quad 0.006 *$

$0.005 \quad 0.079$

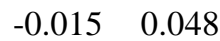

$0.5520 .208 * *$

$0.1620 .055^{* * * *}$

$3.6151 .675 * *$

$0.091 \quad 0.145$

$\begin{array}{ll}-0.429 & 0.260\end{array}$

$0.0200 .007 * * *$

$-0.0520 .020 * *$

$0.0790 .020 * * *$

$0.9290 .202 * * *$

$0.1650 .096^{*}$

Estimation of difference between long-run effects on large-bank and small-bank variables ${ }^{1}$

$\begin{array}{lrrrrrrrrr} & \text { Difference } & \underline{\text { Std. error }} & \underline{\text { Difference }} & \underline{\text { Std. error }} & \underline{\text { Difference }} & \underline{\text { Std. error }} \\ \text { Leverage ratio } & 0.169 & 0.128 & & 0.203 & 0.206 & & 0.390 & 0.230^{*} \\ \text { Real return on loans } & -0.021 & 0.150 & & -0.290 & 0.742 & & -1.002 & 0.344^{* * *} \\ \text { Deposit share of MMMF + thrifts } & -0.103 & 0.055^{*} & & 0.113 & 0.126 & -0.068 & 0.106 \\ \text { Uninsured share of deposits } & 0.027 & 0.025 & & -0.031 & 0.067 & 0.112 & 0.063^{*} \\ \text { Real deposit rate at other bank group } & 0.277 & 0.128^{* *} & & 0.143 & 0.616 & 0.453 & 0.319\end{array}$

Notes: Each variable is entered as the level of the underlying series, unless otherwise noted, and the instrument for each variable is the second lag of that variable. The equations for each deposit type were estimated jointly for small and large banks using Seemingly Unrelated Regression. Standard errors are corrected for autocorrelation and heteroskedasticity.

$*$ P-value $<0.10, * *$ p-value $<0.05, * * *$ p-value $<0.01$

${ }^{1}$ Small bank less large bank. Long-run effect $=$ coefficient/( $1-$ coefficient on lagged dependent variable $)$ 